\title{
Highly resolved observations of trace gases in the lowermost stratosphere and upper troposphere from the Spurt project: an overview
}

\author{
A. Engel ${ }^{1}$, H. Bönisch ${ }^{1}$, D. Brunner ${ }^{5}$, H. Fischer ${ }^{3}$, H. Franke ${ }^{6}$, G. Günther ${ }^{2}$, C. Gurk ${ }^{3}$, M. Hegglin ${ }^{5}$, P. Hoor ${ }^{3}$, \\ R. Königstedt ${ }^{3}$, M. Krebsbach ${ }^{2}$, R. Maser ${ }^{6}$, U. Parchatka ${ }^{3}$, T. Peter ${ }^{5}$, D. Schell ${ }^{6}$, C. Schiller ${ }^{2}$, U. Schmidt ${ }^{1}$, N. Spelten ${ }^{2}$, \\ T. Szabo ${ }^{4}$, U. Weers ${ }^{3}$, H. Wernli ${ }^{4}$, T. Wetter ${ }^{1}$, and V. Wirth ${ }^{4}$ \\ ${ }^{1}$ Institut für Atmosphäre und Umwelt, J. W. Goethe Universität Frankfurt, Germany \\ ${ }^{2}$ Institut für Chemie und Dynamik der Geosphäre, ICG-I, Forschungszentrum Jülich, Germany \\ ${ }^{3}$ Max-Planck-Institut für Chemie, Mainz, Germany \\ ${ }^{4}$ Institut für Physik der Atmosphäre, Universität Mainz, Germany \\ ${ }^{5}$ Institute for Atmospheric and Climate Science, ETH Zürich, Switzerland \\ ${ }^{6}$ Enviscope GmbH, Frankfurt, Germany
}

Received: 13 May 2005 - Published in Atmos. Chem. Phys. Discuss.: 20 July 2005

Revised: 19 October 2005 - Accepted: 12 December 2005 - Published: 2 February 2006

\begin{abstract}
During SPURT (Spurenstofftransport in der Tropopausenregion, trace gas transport in the tropopause region) we performed measurements of a wide range of trace gases with different lifetimes and sink/source characteristics in the northern hemispheric upper troposphere (UT) and lowermost stratosphere (LMS). A large number of in-situ instruments were deployed on board a Learjet 35A, flying at altitudes up to $13.7 \mathrm{~km}$, at times reaching to nearly $380 \mathrm{~K}$ potential temperature. Eight measurement campaigns (consisting of a total of 36 flights), distributed over all seasons and typically covering latitudes between $35^{\circ} \mathrm{N}$ and $75^{\circ} \mathrm{N}$ in the European longitude sector $\left(10^{\circ} \mathrm{W}-20^{\circ} \mathrm{E}\right)$, were performed. Here we present an overview of the project, describing the instrumentation, the encountered meteorological situations during the campaigns and the data set available from SPURT. Measurements were obtained for $\mathrm{N}_{2} \mathrm{O}, \mathrm{CH}_{4}, \mathrm{CO}$, $\mathrm{CO}_{2}, \mathrm{CFC} 12, \mathrm{H}_{2}, \mathrm{SF}_{6}, \mathrm{NO}, \mathrm{NO}_{\mathrm{y}}, \mathrm{O}_{3}$ and $\mathrm{H}_{2} \mathrm{O}$. We illustrate the strength of this new data set by showing mean distributions of the mixing ratios of selected trace gases, using a potential temperature-equivalent latitude coordinate system. The observations reveal that the LMS is most stratospheric in character during spring, with the highest mixing ratios of $\mathrm{O}_{3}$ and $\mathrm{NO}_{\mathrm{y}}$ and the lowest mixing ratios of $\mathrm{N}_{2} \mathrm{O}$ and $\mathrm{SF}_{6}$. The lowest mixing ratios of $\mathrm{NO}_{\mathrm{y}}$ and $\mathrm{O}_{3}$ are observed during autumn, together with the highest mixing ratios of $\mathrm{N}_{2} \mathrm{O}$ and $\mathrm{SF}_{6}$ indicating a strong tropospheric influence. For $\mathrm{H}_{2} \mathrm{O}$, however, the maximum concentrations in the LMS are found during summer, suggesting unique (temperature-
\end{abstract}

Correspondence to: A. Engel

(an.engel@meteor.uni-frankfurt.de) and convection-controlled) conditions for this molecule during transport across the tropopause. The SPURT data set is presently the most accurate and complete data set for many trace species in the LMS, and its main value is the simultaneous measurement of a suite of trace gases having different lifetimes and physical-chemical histories. It is thus very well suited for studies of atmospheric transport, for model validation, and for investigations of seasonal changes in the UT/LMS, as demonstrated in accompanying and elsewhere published studies.

\section{Introduction}

SPURT (Spurenstofftransport in der Tropopausenregion, trace gas transport in the tropopause region) was a project under the German AFO 2000 programme. The main aim of SPURT was to measure trace species in the UT/LMS (Upper Troposphere/Lowermost Stratosphere) region and to use these observations to improve our understanding of the transport processes governing this region, with a focus on the transport pathways into the LMS. Hoskins et al. (1985) defined the LMS as the part of the lower stratosphere which is accessible from the troposphere along isentropic surfaces. The conceptual framework for trace gas transport into the LMS was laid by Holton et al. (1995), who identified two main transport pathways: (1) diabatic descent from above, i.e. air entering the LMS from the overworld (i.e., above the $380 \mathrm{~K}$ potential temperature level), and (2) isentropic transport across the extratropical tropopause. Since the extratropical tropopause is marked by a sharp increase in potential

(C) 2006 Author(s). This work is licensed under a Creative Commons License. 
vorticity (PV), it is, however, clear that air can not move freely across the tropopause, not even along isentropes. During the last decade numerous studies have tried to quantify the contribution of different source regions to the budget of the lowermost stratosphere, based on observations (e.g. Hintsa et al., 1998; Ray et al., 1999; Pan et al., 2000; Hoor et al., 2005; Hegglin et al., 2004), Lagrangian transport studies (e.g. Dethof et al., 2000; Seo and Bowman, 2001; Wernli and Bourqui, 2002; Sprenger and Wernli, 2003; Stohl et al., 2003) and model based budget investigations (e.g. Appenzeller et al., 1996; Schoeberl, 2004). It has become clear from these studies, that the trace gas composition of the UT/LMS shows a pronounced seasonal variability, sometimes being dominated by stratospheric air, sometimes showing more tropospheric character. Fischer et al. (2000) and Hoor et al. (2002) showed that the lowermost stratosphere is not entirely well mixed. Above the tropopause, a layer, called the mixing layer by Fischer et al. (2000), is found where trace gases show intermediate values between typical tropospheric values and typical stratospheric values. In agreement with this, the observed seasonal variability of ozone changes rapidly above the tropopause. Brunner et al. (2001) found a typical upper tropospheric cycle at the lower boundary of this layer (i.e. on the $2 \mathrm{PVU}$ potential vorticity surface), while a typical stratospheric ozone seasonality was observed at the upper limit of this layer (i.e. at about 3.5 PVU). With respect to trace gas transport, the tropopause is thus not a sharp barrier, but rather a a transition zone with characteristics changing between those of the well mixed troposphere and those of the stably layered stratosphere

Hintsa et al. (1994) and Rosenlof et al. (1997) showed that the seasonal cycle of water vapour in the tropical lower stratosphere, which is due to the seasonal cycle of tropical tropopause temperatures (e.g. Mote et al., 1996), can also be observed at mid latitudes at levels with $\mathrm{N}_{2} \mathrm{O}$ mixing ratios as low as about $250 \mathrm{ppb}$, which is well inside the stratospheric overworld. Boering et al. (1996) found a similar behaviour for $\mathrm{CO}_{2}$, where the seasonality in $\mathrm{CO}_{2}$ mixing ratios is due to the tropospheric seasonality. Rosenlof et al. (1997) used a combination of satellite and aircraft observations to investigate the transport of water vapour into and within the lower stratosphere. They concluded, that a "tropically controlled transition layer" exists in the mid latitude lower stratosphere which extends from the $380 \mathrm{~K}$ surface to about $450 \mathrm{~K}$ potential temperature, and which is influenced on rather short time scales (on the order of months) by transport from the tropics. Similar results were found by Boering et al. (1994) based on $\mathrm{CO}_{2}$ and $\mathrm{N}_{2} \mathrm{O}$ observations, Rosenlof et al. (1997) observed the $\mathrm{H}_{2} \mathrm{O}$ minimum in the Northern Hemisphere lower stratosphere between 30 and $40^{\circ} \mathrm{N}$ around March, whereas the minimum in the tropics is found in January, i.e. about two months earlier. Downward transport of air from this tropically controlled transition layer might serve as an additional pathway to enter the lowermost stratosphere for air masses which still have tropospheric characteristics. In con- trast to tropospheric air masses transported across the extratropical tropopause, these air masses originate in the tropical tropopause region. The observations of a seasonal cycle in trace species or of relatively high mixing ratios of age tracers such as $\mathrm{SF}_{6}$ (which indicates young air) in the lowermost stratosphere, is therefore not necessarily an indication of transport across the extratropical tropopause. In addition, recent observations and model studies (e.g. Fromm et al., 2000; Wang, 2003) have revealed that pyro-convection or high reaching convection in large storms can transport air from the mid latitude boundary layer to the lowermost stratosphere in a very short time. In order to explain the trace gas compositions in the lowermost stratosphere, all the transport pathways described above have to be taken into account.

The tropopause region is important with respect to the atmospheric chemical and radiative budgets. Due to the fact that the LMS is dynamically more closely coupled to the troposphere (as opposed to the overworld stratosphere), shortlived pollutants of tropospheric origin are more likely to propagate into the LMS than into the overworld stratosphere. A significant temporal decrease in $\mathrm{O}_{3}$ has been observed in the midlatitude lower stratosphere (Logan et al., 1999; Fioletov et al., 2002), but trends in the LMS are not well known due to large dynamical variability and appear to vary strongly with season and location (Logan et al., 1999) and with the considered time period (WMO, 2003). Changes in the chemical composition of the UT/LMS region strongly affect the atmospheric radiative budget and in particular the efficiency of ozone as a greenhouse gas peaks around the tropopause (e.g. Lacis et al., 1990; Van Dorland and Fortuin, 1994; Forster and Shine, 1997). Especially the variability of the chemical composition and the processes controlling this variability need to be understood.

In the following we present the SPURT objectives, the measurement capabilities and the campaign concept. We then describe the measurements performed during SPURT and the meteorological situations encountered during the individual campaigns. Finally, we give an overview of the $\mathrm{N}_{2} \mathrm{O}, \mathrm{CO}, \mathrm{O}_{3}, \mathrm{SF}_{6}, \mathrm{CO}_{2}, \mathrm{NO}_{\mathrm{y}}$ and $\mathrm{H}_{2} \mathrm{O}$ data using potential temperature and equivalent latitude as reference coordinates and grouping the data by season (with two campaigns for each season). Detailed scientific results are subject of specific papers, which are listed at the end of this overview.

\section{The scientific aim of SPURT}

The aim of SPURT was to provide a high quality data set for a number of trace gases with different lifetimes and different source-sink characteristics in the UT/LMS for each of the four seasons. Data of sufficient quality and coverage in this region are still sparse. Programmes using commercial aircraft (e.g. Marenco et al., 1998; Brenninkmeijer et al., 1999; Brunner et al., 2001) only reach the lower part of the extratropical lowermost stratosphere, and satellite data do not 
have sufficient vertical and horizontal resolution in order to catch the fine scale structures present in the lowermost stratosphere. Dedicated aircraft campaigns investigating the lowermost stratosphere mostly focussed on observing special situations where TST (troposphere-to-stratosphere transport) or STT (stratosphere-to-troposphere transport) are expected to occur. In contrast, SPURT was designed to establish a comprehensive data set with good seasonal and latitudinal coverage of the LMS, which could in the future and in combination with data from other sources lead towards a climatology of the air mass composition in the UT/LMS, rather than to focus on special events which could introduce a bias in the results obtained. A total of eight measurement campaigns were performed in a cost- and time-efficient way using a Learjet 35A aircraft, which is able to reach altitudes of up to $13.7 \mathrm{~km}$. The aircraft was equipped with in-situ instrumentation for the measurement of a large variety of tracers with different lifetimes and sink-source distributions, which included $\mathrm{CO}$, $\mathrm{O}_{3}, \mathrm{NO}, \mathrm{NO}_{\mathrm{y}}, \mathrm{CH}_{4}, \mathrm{~N}_{2} \mathrm{O}, \mathrm{CFC}-12, \mathrm{H}_{2}, \mathrm{SF}_{6}, \mathrm{CO}_{2}$ and $\mathrm{H}_{2} \mathrm{O}$. During each campaign the UT/LMS over Europe was probed between about $35^{\circ} \mathrm{N}$ and $75^{\circ} \mathrm{N}$.

The primary scientific goal was to investigate how the trace gas distribution in the UT/LMS varies with latitude and season. The data allow gaining insight into the dynamical and chemical processes that govern the variability of trace gas mixing ratios in this region. Although for climatological studies of variability a much larger data set is necessary, systematic variations between seasons can be derived from the data provided adequate reference coordinates are chosen. Hoor et al. (2004a, b), Hegglin et al. (2005a) and Krebsbach et al. $\left(2005 \mathrm{a}, \mathrm{b}^{1}\right)$ showed that a substantial amount of scatter in the observations can be removed by representing the data in a potential temperature versus equivalent latitude coordinate system, because this accounts for the influence of transient (and largely reversible) north-south excursions of air parcels associated with Rossby and other waves, which significantly contribute to the variability in geographical space. Using this coordinate system they were able to construct characteristic trace gas distributions for each season. These distributions are largely determined by seasonal differences in transport processes, i.e. the downward transport from the overworld, the meridional transport of air in the lower stratosphere from the tropics to mid and high latitudes above the $380 \mathrm{~K}$ isentropic surface, and the coupling between the extratropical UT and LMS below $380 \mathrm{~K}$. In addition, the water vapour data allow investigating the effect of freeze-drying at the tropical and extratropical tropopause. The age tracers $\mathrm{CO}_{2}$ and $\mathrm{SF}_{6}$ serve to derive typical transport times for air to reach the LMS. The mixing of air masses with different chemical characteristics (e.g. tropospheric and strato-

\footnotetext{
${ }^{1}$ Krebsbach, M., Brunner, D., Günther, G., Hegglin, M., Spelten, N., and Schiller, C.: Characteristics of the extratropical transition layer as derived from $\mathrm{H}_{2} \mathrm{O}$ and $\mathrm{O}_{3}$ measurements in the UT/LS, Atmos. Chem. Phys. Discuss., to be submitted, 2005b.
}

spheric), down to scales below the resolution of the observations, leads to changes in correlations between trace species which can be investigated with the SPURT data set. Furthermore, the data are also useful for case studies (e.g. Hegglin et al., 2004) of atmospheric transport processes.

\section{Instrumentation and data treatment}

\subsection{The SPURT payload}

The aircraft used as a platform for the SPURT observations is a Learjet 35A operated by the company GFD (Gesellschaft für Flugzieldarstellung) in Hohn, Northern Germany $\left(52^{\circ} \mathrm{N} / 6^{\circ} \mathrm{E}\right)$ in cooperation with the company enviscope. The aircraft reaches a maximum altitude of about $13.7 \mathrm{~km}$ and has a range of about $4000 \mathrm{~km}$, while carrying a scientific payload of about $1000 \mathrm{~kg}$. The payload for SPURT consisted of an in-situ gas chromatograph (GhOST II), a tuneable diode laser absorption spectrometer (TRISTAR), a Lyman- $\alpha$ fluorescence hygrometer (FISH), a chemiluminescence instrument (ECO), an ozone photometer (JOE) and a non-dispersive infrared spectrometer (FABLE). The measurement capabilities, including typical precisions and accuracies, as well as time resolutions are summarised in Table 1.

Beside this scientific instrumentation, which is explained in detail in the following sections, standard avionic and meteorological data were provided by GFD/enviscope. A set of sensors for temperature, differential and static pressure, a data acquisition, and interfaces to the permanently installed aircraft sensors (e.g. GPS antennas, air data computer) was installed in the beginning of each SPURT campaign. This basic instrumentation set allows to retrieve position data, static temperature, static and dynamic pressure, true airspeed and mean horizontal wind speed and direction.

\subsubsection{GhOST II}

The gas chromatograph GhOST II (Wetter, 2002) is a three channel gas chromatograph, which was developed based on the GhOST instrument described by Bujok et al. (2001). GhOST II compresses outside air by means of a diaphragm pump, then injects samples of this compressed air onto three gas chromatographic columns. Two columns are equipped with ECD detectors for the measurement of CFC 12, $\mathrm{SF}_{6}$ and $\mathrm{N}_{2} \mathrm{O}$. These compounds are calibrated relative to the NOAA/CMDL scale (e.g. Elkins et al., 1993; Montzka et al., 1996). The third column is equipped with a Reduction Gas Detector (RGD) to measure $\mathrm{H}_{2}$ and $\mathrm{CO}$. The measurements are corrected for detector non-linearities and for effects of the cross interference of $\mathrm{CO}_{2}$ on the $\mathrm{N}_{2} \mathrm{O}$ measurements.

\subsubsection{TRISTAR}

The three channel Tunable Diode Laser Absorption Spectrometer (TDLAS) TRISTAR (Tracer in situ TDLAS for 
Table 1. SPURT measurement equipment. As some of the instruments have been improved during the project, this table reflects the latest state of the measurement possibilities.

\begin{tabular}{|c|c|c|c|c|c|c|}
\hline Instrument & Institution & Technique & Species & Resolution [s] & Precision & Accuracy \\
\hline GhOST II & JWGU-IMG & In-situ GC & $\begin{array}{l}\mathrm{SF}_{6}, \mathrm{CFC}- \\
12, \quad \mathrm{~N}_{2} \mathrm{O} \\
\mathrm{CO}, \mathrm{H}_{2}\end{array}$ & 70 & $\begin{array}{ll}<1 \% \text { for all, } \\
<0.5 \% \text { for } \\
\mathrm{N}_{2} \mathrm{O} \text { and } \\
\mathrm{CFC}-12\end{array}$ & $\begin{array}{ll}<2 \% \text { for all, } & <1.5 \% \text { for } \\
\mathrm{N}_{2} \mathrm{O} & \text { and } \\
\mathrm{CFC}-12 & \end{array}$ \\
\hline TRISTAR & MPICH-LC & TDL & $\begin{array}{l}\mathrm{CH}_{4}, \\
\mathrm{~N}_{2} \mathrm{O}, \mathrm{CO}\end{array}$ & 5 & $\begin{array}{l}1 \% \text { for all } \\
\text { species }\end{array}$ & $\begin{array}{l}2 \% \text { for all } \\
\text { species }\end{array}$ \\
\hline FABLE & MPICH-LC & IR-spectroscopy & $\mathrm{CO}_{2}$ & 1 & & $0.3 \mathrm{ppm}$ \\
\hline FISH & FZJ-ICG-I & $\begin{array}{l}\text { Lyman- } \alpha \\
\text { Fluorescence }\end{array}$ & $\mathrm{H}_{2} \mathrm{O}$ & 1 & $<3 \%$ & $6 \%$ \\
\hline JOE & FZJ-ICG-I & $\mathrm{O}_{3}$ Photometer & $\mathrm{O}_{3}$ & $10 / 4$ & $<3 \%$ & $5 \%$ \\
\hline \multirow[t]{2}{*}{ ECO } & ETH-Z & chemiluminescence & $\mathrm{NO}, \mathrm{O}_{3}$ & 1 & $\begin{array}{l}9 \text { pptv, } \\
149 \text { pptv } \\
\text { for } \mathrm{O}_{3}\end{array}$ & $\begin{array}{l}4.5 \% \text { for } \mathrm{NO}, \\
5 \% \text { for } \mathrm{O}_{3}\end{array}$ \\
\hline & $\begin{array}{l}\text { ETH-Z, } \\
\text { MPICH-LC }\end{array}$ & $\begin{array}{l}\text { AU-converter with } \\
\text { chemiluminescence }\end{array}$ & $\mathrm{NO}_{\mathrm{y}}$ & 1 & $11 \mathrm{pptv}$ & $16 \%$ \\
\hline
\end{tabular}

atmospheric research, Wienhold et al., 1998; Kormann et al., 2002) was used to measure in situ $\mathrm{CO}, \mathrm{CH}_{4}$ and $\mathrm{N}_{2} \mathrm{O}$. The ultimate time resolution of $5 \mathrm{~s}$ is determined by the subsequent measurement of each individual channel with an integration time of $1.3 \mathrm{~s}$. The instrument is calibrated in-flight every 10 min against secondary standards of dried compressed air which are cross calibrated against long term laboratory primary standards of NOAA and NIWA. The overall uncertainty is determined from the reproducibility of the in-flight calibrations. After post flight data processing we typically achieved a reproducibility of the in-flight calibrations of $1.0 \%, 1.5 \%$ and $2.5 \%$, for $\mathrm{N}_{2} \mathrm{O}, \mathrm{CO}$, and $\mathrm{CH}_{4}$, respectively. The errors are slightly larger during ascent and descent.

\subsubsection{FABLE}

To measure $\mathrm{CO}_{2}$ we used the modified Li-COR 6262 NDIRinstrument FABLE (Fast AirBorne Licor Experiment). The instrument was pressure- and temperature-stabilized to minimize sensitivity changes. Time resolution was $1 \mathrm{~Hz}$ and $\mathrm{ul}-$ timately limited by the flow rate through the system. The instrument was in flight calibrated against secondary standards of dried compressed ambient air. To account for the nonlinearity of the instrument and to guarantee long term stability the setup was cross calibrated against primary standards of NOAA-CMDL with different $\mathrm{CO}_{2}$-content. With this setup the total uncertainty is estimated to be better than $0.3 \mathrm{ppmv}$ (Gurk, 2003).

\subsubsection{FISH}

The Fast In-situ Stratospheric Hygrometer (FISH) is an instrument to measure $\mathrm{H}_{2} \mathrm{O}$ using the Lyman- $\alpha$ photofragment fluorescence technique. Details of the instrument are de- scribed in Zöger et al. (1999). The instrument is calibrated in the laboratory before and after each mission and during the SPURT campaigns at each stopover at the home base in Hohn using a calibration bench with a frost point hygrometer as a reference instrument. FISH is sensitive to make $\mathrm{H}_{2} \mathrm{O}$ measurements in the range from about 500-0.2 ppmv in the UTLS. For stratospheric mixing ratios, the overall accuracy is $6 \%$ and the precision $0.15 \mathrm{ppmv}$ at $1 \mathrm{~s}$ time resolution. During SPURT, FISH was equipped with a forward-facing inlet of $10 \mathrm{~mm}$ inner diameter. Thus the total water, i.e. the sum of gas-phase and condensed cloud or ice water was measured. Data in clouds are corrected for oversampling in the anisokinetic inlet.

\subsubsection{ECO}

$\mathrm{NO}_{\mathrm{y}}, \mathrm{NO}$, and $\mathrm{O}_{3}$ were measured using a fast and highly sensitive chemiluminescence analyzer (ECO Physics CLD 790 SR) with three independent channels. Total reactive nitrogen $\left(\mathrm{NO}_{\mathrm{y}}\right)$ was reduced to $\mathrm{NO}$ prior to the measurement by using an externally mounted catalytic gold converter with $\mathrm{CO}$ as reduction agent (Fahey et al., 1985; Lange et al., 2002). NO then was measured by chemiluminescence, by letting NO react with an excess of $\mathrm{O}_{3} \cdot \mathrm{O}_{3}$ was measured based on the same principle but with an excess of NO. The instrument was calibrated in-flight, before and after each campaign with known amounts of $\mathrm{NO}, \mathrm{NO}_{2}$, and $\mathrm{O}_{3}$ to account for changing operating conditions such as temperature and pressure that influence the performance of the instrument. The precision of the $\mathrm{NO}_{\mathrm{y}}, \mathrm{NO}$, and $\mathrm{O}_{3}$ data with a resolution of $1 \mathrm{~Hz}$ were $11 \mathrm{pptv}, 9 \mathrm{pptv}, 149 \mathrm{pptv}$, respectively. The accuracy of the measurements was $16 \%$ for $\mathrm{NO}_{\mathrm{y}}, 4.5 \%$ for $\mathrm{NO}$ and $5 \%$ for $\mathrm{O}_{3}$. All these values are based on a $2 \sigma$ confidence level. 
A more detailed description of the ECO-instrumentation is given in Hegglin et al. (2005a).

\subsubsection{JOE}

Ozone was also measured by UV absorption using the Jülich Ozone Experiment (JOE). JOE is based on a commercial Thermo Electron Corporation two-stream monitor (model TE 49C) which was modified for operation at reduced pressure of the probed air and in the aircraft environment (Mottaghy, 2001). The instrument was regularly calibrated against a laboratory instrument (TE 49C Primary Standard). The accuracy of the ozone monitor is $5 \%$ and can be operated to a precision of $2.5 \mathrm{ppbv}$ at an integration time of $10 \mathrm{~s}$. For the use in the SPURT merged data files, JOE data are interpolated to 4 or $5 \mathrm{~s}$ intervals.

\subsection{Instrument intercomparisons}

Several trace gases were measured with different instruments. In particular $\mathrm{O}_{3}, \mathrm{~N}_{2} \mathrm{O}$ and $\mathrm{CO}$ were measured by two instruments which should deliver data of comparable quality. The CO data set obtained from GhOST II is rather small and the instrument was not very well characterized for this species. While in general the tropospheric data of $\mathrm{CO}$ showed reasonable agreement between GhOST II and TRISTAR, the GC yielded higher values at low mixing ratios. This could either be due to an in-situ CO production in the instrument or to a poor detector characterisation. However, the CO data of GhOST II were not used widely, so no thorough data intercomparison has been performed. After the SPURT 7 campaign (see below) an $\mathrm{NO}_{\mathrm{y}}$ intercomparison flight was performed with the MOZAIC $\mathrm{NO}_{\mathrm{y}}$ instrument (Volz-Thomas et al., 2005), yielding satisfactory agreement with ECO. Results from this intercomparison is presented in a separate paper (Paetz et al., 2006). The intercomparisons detailed in the following, are, therefore, restricted to the $\mathrm{N}_{2} \mathrm{O}$ and $\mathrm{O}_{3}$ data.

\subsubsection{Intercomparison $\mathrm{JOE}-\mathrm{O}_{3}$ and $\mathrm{ECO}-\mathrm{O}_{3}$}

$\mathrm{O}_{3}$ was measured by the Juelich Ozone Experiment (JOE) using photometry and simultaneously by ECO using chemiluminescence. Beside the two different measurement techniques the two instruments differ by their time resolution of $<1 \mathrm{~s}$ for the ECO- and $10 \mathrm{~s}$ for the JOE-instrument.

For the following evaluation of the two instruments, the collected data of campaign SPURT 7 (see Sect. 4.2) was chosen due to the large dynamical range between 50 and $1000 \mathrm{ppbv} \mathrm{O}_{3}$. Figure 1 shows the scatter plot of the two instruments with a linear least-square approximation of the data, taking into account errors in both coordinates. In addition, the expected one-to-one correlation line is given. The correlation was calculated for all data points collected during the five flights of SPURT-7 resulting in a total of 9823 data points. The primary data was merged to $5 \mathrm{~s}$ values in averaging the $\mathrm{ECO} \mathrm{O}_{3}$ with a sample rate of $1 \mathrm{~s}$ over a $5 \mathrm{~s}$ interval

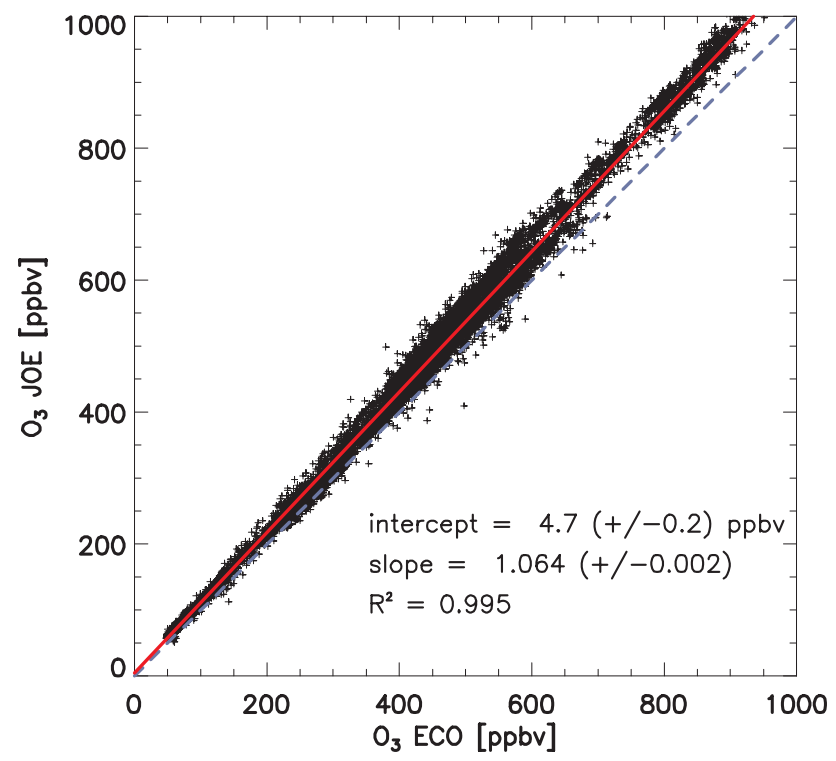

Fig. 1. Least-square approximation of a linear fit between the $\mathrm{O}_{3}$ data from JOE and ECO (red solid line). The dashed blue line indicates the one-to-one correlation.

and interpolating the JOE $\mathrm{O}_{3}$ with sample rate of $4 \mathrm{~s}$ to the center of each interval. The resulting data is clustered around a straight line with a correlation coefficient of 0.995 , indicating that the two data sets are in close agreement. The best linear fit parameters for the slope and the intercept indicate that there is still a significant systematic difference between the two instruments: the slope of $1.064( \pm 0.002)$ indicates a $6.4 \%$ difference in the two separately collected data sets. This difference is, however, well within the combined overall uncertainties of the two instruments.

\subsubsection{Intercomparison GhOST II $\mathrm{N}_{2} \mathrm{O}$ and TRISTAR- $\mathrm{N}_{2} \mathrm{O}$}

As in the case of $\mathrm{O}_{3}, \mathrm{~N}_{2} \mathrm{O}$ was measured with two completely independent techniques on board the Learjet. The TDL spectrometer TRISTAR provides high resolution data at a time resolution of $5 \mathrm{~s}$ whereas the GC GhOST II measures $\mathrm{N}_{2} \mathrm{O}$ with a time resolution of 60 to $90 \mathrm{~s}$ (depending on the chromatographic set-up). Both instruments (or their predecessors) have been intercompared previously (Bujok et al., 2000; Hoor et al., 1999) and were shown to agree within their specified errors. The $\mathrm{N}_{2} \mathrm{O}$ observations during the SPURT campaign only span mixing ratios between about 270 and $320 \mathrm{ppbv}$, giving a low dynamical range, which implies that high precision and accuracy of the data are required. The reproducibility of GHOST II increased due to analytical improvements between SPURT-2 and SPURT-3 from about $1.5 \%$ to better than $0.8 \%$. During SPURT- 4 and SPURT-5 the precision was better than $0.5 \%$, and about $0.3 \%$ during all later measurements. Averaged over all campaigns the mean reproducibility was $0.56 \%$. The precision of the TRISTAR TDL is typically $1 \%$ for $\mathrm{N}_{2} \mathrm{O}$, being slightly reduced during 

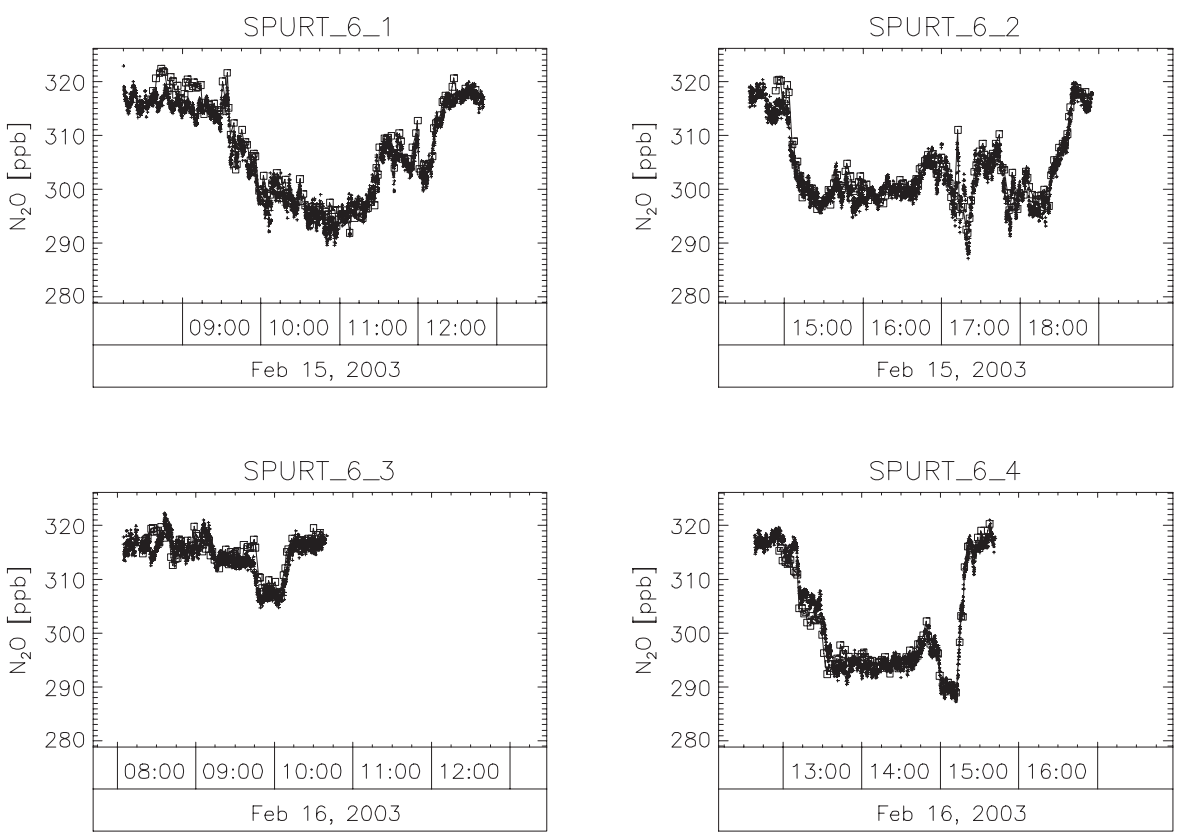

Fig. 2. Direct intercomparision of $\mathrm{N}_{2} \mathrm{O}$ time series measured by GhOST II (open squares) and by TRISTAR (points). Due to the much higher sampling frequency, the TDL data set is much larger than the GC data. However, also small scale features are well captured by both instruments, e.g. the spike in the data observed during flight SPURT6_2 around 17:10 UTC.

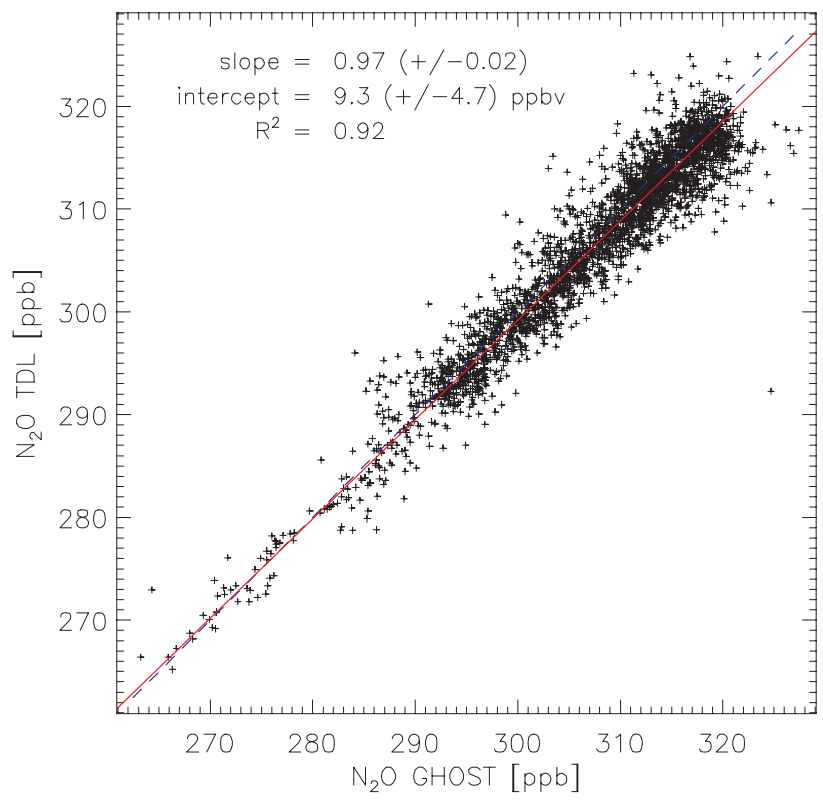

Fig. 3. Least-square approximation of a linear fit between the $\mathrm{N}_{2} \mathrm{O}$ data of TRISTAR and GhOST II. The dynamical range for the correlation (red line) is much lower than for ozone (cf. Fig. 1), which results in a lower regression coefficient. The dashed blue line represents the expected 1:1 correlation line.

the initial ascents and final descents and during SPURT- 1 and SPURT-2. Figure 2 shows the direct comparison between TRISTAR and GhOST II observations during the flights of the SPURT-6 campaign. Even small scale structures are reproduced very well by both instruments. Figure 3 shows the scatter plot between GHOST II observations and TRISTAR measurements at the same time (due to the higher time resolution of TRISTAR only a small fraction of the TRISTAR data are included in the plot). The scatter around the regression line is $0.91 \%$ ( 1 sigma), which is well below the combined stated precisions of both instruments, showing that the error estimates are conservative.

\subsection{Data post-processing}

Measurements from the different instruments were obtained at different sampling intervals and at different time lags due to the varying sampling properties and instrumental response times. A cross-correlation analysis was therefore performed on pairs of observations from a single flight in order to assess a time lag correction for each instrument. These corrections were in the range of 1 to $8 \mathrm{~s}$ depending on the instrument and were found to vary by no more than 1 to $2 \mathrm{~s}$ between the different flights and campaigns.

Data recorded by the individual instruments and the Learjet flight data system were finally combined into a single "merge file" with a time resolution of $5 \mathrm{~s}$, which is available for each flight in addition to the instrument-specific data files. Meteorological data from operational ECMWF analysis fields interpolated from the model grid onto the flight tracks were also included in the merge files. ECMWF data with a three hour time resolution, 60 vertical layers and 
Table 2. SPURT campaigns, with dates, number of flight hours, number of flights and number of days the aircraft was booked.

\begin{tabular}{lllll}
\hline Campaign & Flight dates & Flight hours & No. of flights & No. of aircraft days \\
\hline SPURT-01 & 10/11 Nov 2001 & $15: 33$ & 4 & 5 \\
SPURT-02 & 17-19 Jan 2002 & $21: 28$ & 6 & 5 \\
SPURT-03 & 16/17 May 2002 & $18: 48$ & 4 & 4 \\
SPURT-04 & 22/23 Aug 2002 & $14: 59$ & 4 & 4 \\
SPURT-05 & 17/18 Oct 2002 & $17: 22$ & 4 & 4 \\
SPURT-06 & 15/16 Feb 2003 & $19: 36$ & 5 & 4 \\
SPURT-07 & 27-29 April 2003 & $18: 00$ & 5 & 5 \\
SPURT-08 & 9/10 July 2003 & $17: 01$ & 4 & 4 \\
Sum & & $142: 47$ & 36 & 35 \\
\hline
\end{tabular}

a $1.0 \times 1.0$ degree resolution were used. These files comprise temperature, winds, humidity, potential vorticity, and equivalent latitude. Equivalent latitude $\left(\phi_{e}\right)$ versus PV relations were first calculated from the PV distributions on 14 isentropic surfaces between 270 and $400 \mathrm{~K}$ to obtain a twodimensional field $\phi_{e}(\mathrm{PV}, \theta)$, which was then linearly interpolated onto the ECMWF model PV and potential temperature values along the flight track.

10-day backward trajectories based on 3-hourly ECMWF fields of horizontal and vertical winds were started every $10 \mathrm{~s}$ along the flight track using the LAGRANTO trajectory tool (Wernli and Davies, 1997). Minimum and maximum values of PV, temperature, latitude and relative humidity along the trajectories as well as the number of hours since the last tropopause crossing (defined as change from above/below to below/above 2 PVU) were also stored in the merge files. All these ancillary data proved useful for the analysis and interpretation of the observations.

\subsection{Data availability}

The data can be freely downloaded from http://www.iac.ethz. $\mathrm{ch} / \mathrm{spurt} /$ provided a simple user data protocol is agreed on, stating that the instrument PIs should be informed about the use of their data at an early stage of the investigation and that co-authorship should be offered for publications making use of these data.

\section{The measurement strategy and the SPURT cam- paigns}

\subsection{The measurement strategy}

As the aim of SPURT was to provide observations under typical conditions of the UT/LMS region during all seasons, we performed a total of eight measurement campaigns within an observational period of 2 years from November 2001 until July 2003, probing each season twice. The flight routes of each campaign were covering the UT/LMS in the European longitude sector from high Northern latitudes to the subtropics as far equatorward as possible. In order to achieve this goal under reasonable costs, the campaigns had to be organised in a very efficient way. All instruments were designed to allow fast mounting on the aircraft and were able to measure within one single day. Because of capacity constrictions, only 2 operators were allowed to participate in the flights and thus the instruments had to be automated, so that they could be operated with minimal interference from the board crew. This strategy proved to be very successful, since we were able to perform a SPURT campaign within five days. A typical campaign started with two and a half days for integration and instrument checks on board (including an aircraft seal property test and mass distribution assessment), followed by a first flight day going northward or southward and the second flight day heading in the opposite direction on the following day, provided that no instrument failures occurred. Table 2 shows a summary of the dates, the amount of flight hours and the amount of aircraft booking days for each campaign. The SPURT strategy allowed us to keep aircraft dry leasing costs low, by flying under the given meteorological conditions on fixed days and spending only a minimum time for integrating and testing the instruments.

The two flight days were fixed from the beginning of the campaign and it was our strategy not to wait for any specific meteorological situation with the advantage, that the SPURT data set is not biased by specific conditions. To optimise the flight route, we used the meteorological forecasts prepared by the ETH Zürich based upon operational forecast data from ECMWF for flight planning. The flight in each direction then consisted of an outbound flight, a refuelling stop after about 4 flight hours and then a second flight back to the aircraft base at Hohn. Optionally, the second flight would go further outbound and the base at Hohn would only be reached after a second refuelling stop. In order to achieve an optimal sampling of the UT/LMS the first part of a flight usually consisted of a first level just above the tropopause in the vicinity of the strongest PV-gradients and a second level well above the tropopause. This pattern was mirrored on the return flight 


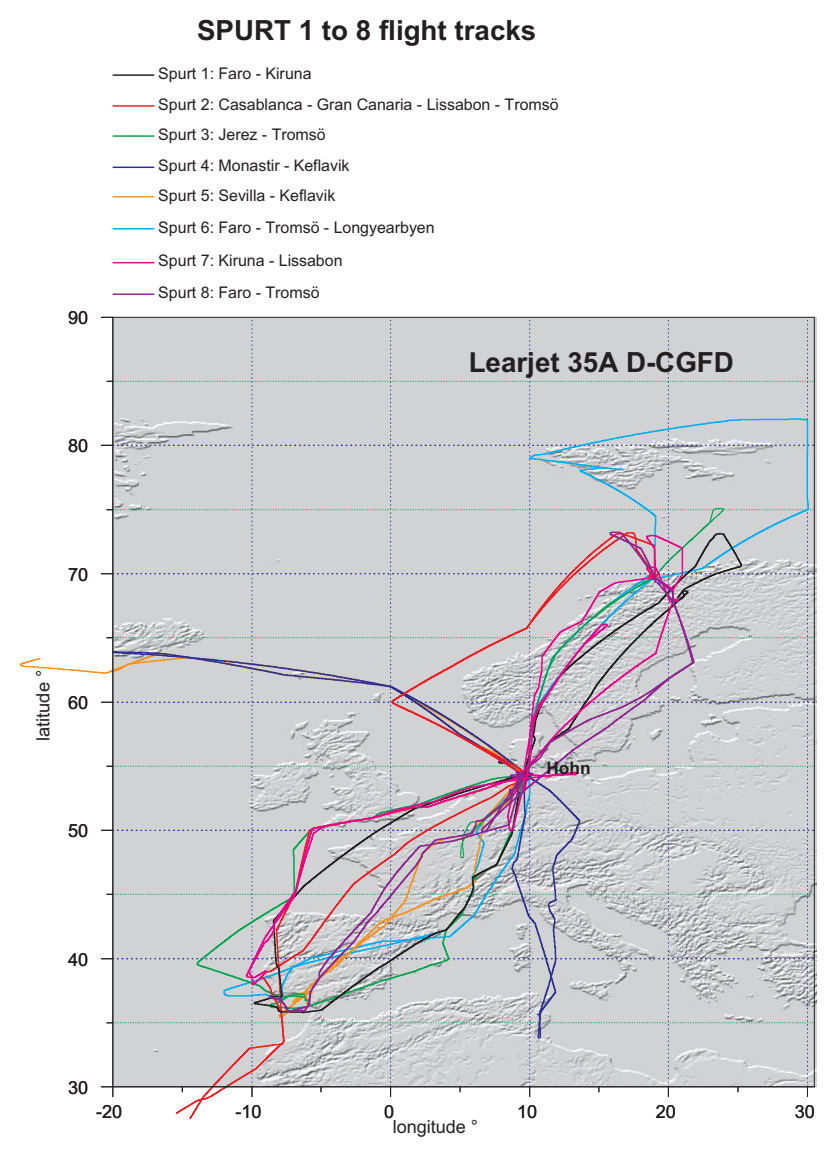

Fig. 4. Flight path of the Learjet for all 8 SPURT measurement campaigns.

on the same day such that each geographical location was sampled twice at two different altitudes. Before each landing the aircraft climbed to maximum altitude followed by a slow descent to the airport in order to obtain highly resolved vertical profiles. Since the airports chosen for intermediate stops mostly were rather small remote airports, we were able to measure clean air vertical profiles during the descent into the airports. The flight path of the Learjet for all campaigns is shown in Fig. 4.

\subsection{The campaigns}

In the following section we give a brief overview of the individual SPURT campaigns, including the dates, flight directions, the meteorological setting, and general information on instrument performance or failures. No details on the individual flights are given, since this would be beyond the scope of this paper. The SPURT campaigns are named chronologically, starting with SPURT-1. If reference is made to an individual flight, the campaign number is followed by the flight number. E.g. flight S3.2 denotes the second flight of the third SPURT campaign. The data availability for the individual flights is summarised in Table 3 . Table 4 summarises some meteorological parameters, the locations, the maximum $\mathrm{O}_{3}$ and the minimum $\mathrm{N}_{2} \mathrm{O}$ mixing ratios for all the individual flights, as an indication on how deep the individual flights reached into the LMS:

\subsubsection{SPURT-1: 10/11 November 2001}

During the first autumn campaign the aircraft flew south to Faro (Portugal), reaching $35^{\circ} \mathrm{N}$ on 10 November 2001. The aircraft was crossing a deep upper level trough during the southbound flight and was flying mostly within the troposphere on the return flight conducted to the west of the trough. The meteorological situation and the measurements during the first flight were described in detail in the case study of Hegglin et al. (2004). On 11 November the northbound leg with a refuelling stop over Kiruna (Sweden) reached $73^{\circ} \mathrm{N}$ before returning to Hohn. All instruments except GHOST II worked well during this campaign. $\mathrm{CO}_{2}$ data are not available for flight S1.2.

\subsubsection{SPURT-2: 17-19 January 2002}

During the first winter campaign the aircraft first headed south to Casablanca, flying mostly within a narrow stratospheric streamer stretching from Great Britain to northern Africa, and then proceeded further south. Due to an overheated fan in the aircraft ventilation system an emergency landing on the Canary Island was necessary. The aircraft reached $27^{\circ} \mathrm{N}$ during this campaign, where the southernmost data available from SPURT were taken. After repair the aircraft returned to Hohn and continued northwards on 19 January, with a refuelling stop in Tromsö (Norway). A tropospheric streamer associated with an elevated tropopause extending from central Europe to Scandinavia was probed twice on these flights to and from Tromsö. Again, the northernmost data from this campaign are from about $73^{\circ} \mathrm{N}$. Data are available from all instruments for this campaign, although some GC data (Flight S2.4) are lacking.

\subsubsection{SPURT-3: 16/17 May 2002}

The synoptic situation during this campaign was dominated by high pressure conditions over central Europe. Again the aircraft first headed south, refuelling in Jerez (Spain). Most of this flight took place in the vicinity of the tropopause. The southern edge of the data available from this campaign is at $36^{\circ} \mathrm{N}$. The northbound flights on 17 May reached deep into the stratosphere over Scandinavia and extended as far north as $75^{\circ} \mathrm{N}$. The stopover was in Tromsö (Norway). Data are available from all instruments for this campaign, the GC data are only complete for $\mathrm{SF}_{6}$.

\subsubsection{SPURT-4: 22/23 August 2002}

Entire Europe was characterized by a flat pressure distribution and a relatively high tropopause. A moderate cyclone 
Table 3. SPURT data availability, sorted by instrument for each flight. $\mathrm{A}=$ data available, $\mathrm{P}=$ data partly available, $-=$ no data. As $\mathrm{O}_{3}$ and $\mathrm{N}_{2} \mathrm{O}$ were measured by two instruments, data for these species are available for all flight. Water vapour is missing for 2 flights, $\mathrm{CO}_{2}$ for 5 flights and $\mathrm{SF}_{6}$ for 7 flights. $\mathrm{NO}_{\mathrm{y}}$ data ar available for all flights.

\begin{tabular}{|c|c|c|c|c|c|c|c|c|c|}
\hline Flight & date & aircraft & TRISTAR & GhOST II & JOE & FISH & ECO & LICOR & MERGE \\
\hline S1.1 & 10 Nov. 2001 & A & A & - & A & A & A & A & A \\
\hline $\mathrm{S} 1.2$ & 10 Nov 2001 & A & A & - & A & A & A & - & A \\
\hline $\mathrm{S} 1.3$ & 11 Nov 2001 & A & A & - & A & A & A & A & A \\
\hline S1.4 & 11 Nov 2001 & A & A & - & A & A & A & A & A \\
\hline S2.1 & 17 Jan 2002 & A & A & A & A & A & A & A & A \\
\hline S2.2 & 17 Jan 2002 & A & A & A & A & A & A & A & A \\
\hline S2.3 & 18 Jan 2002 & A & A & A & A & A & A & A & A \\
\hline S2.4 & 18 Jan 2002 & A & A & - & A & A & A & A & A \\
\hline S2.5 & 19 Jan 2002 & A & A & A & A & A & A & A & A \\
\hline S2.6 & 19 Jan 2002 & A & A & A & A & A & A & A & A \\
\hline S3.1 & 16 May 2002 & A & A & $\mathrm{P}$ & A & A & A & A & A \\
\hline S3.2 & 16 May 2002 & A & A & $\mathrm{P}$ & A & A & A & A & A \\
\hline S3.3 & 17 May 2002 & A & A & A & A & A & A & A & A \\
\hline S3.4 & 17 May 2002 & A & A & A & A & A & A & A & A \\
\hline S4.1 & 22 Aug 2002 & A & A & - & A & A & A & A & A \\
\hline S4.2 & 22 Aug 2002 & A & A & - & A & A & A & A & A \\
\hline S4.3 & 23 Aug 2002 & A & A & A & A & - & A & A & A \\
\hline S4.4 & 23 Aug 2002 & A & A & A & A & - & A & A & A \\
\hline S5.1 & 17 Oct 2002 & A & A & A & A & A & A & A & A \\
\hline S5.2 & 17 Oct 2002 & A & A & A & A & A & A & A & A \\
\hline S5.3 & 18 Oct 2002 & A & A & A & A & A & A & A & A \\
\hline S5.4 & 18 Oct 2002 & A & A & A & A & A & A & A & A \\
\hline S6.1 & $15 \mathrm{Feb} 2003$ & A & A & A & A & A & A & A & A \\
\hline S6.2 & 15 Feb 2003 & A & A & A & A & A & A & A & A \\
\hline S6.3 & 16 Feb 2003 & A & A & A & A & A & A & A & A \\
\hline S6.4 & 16 Feb 2003 & A & A & A & - & A & A & A & A \\
\hline S6.5 & $16 \mathrm{Feb} 2003$ & A & A & A & - & A & A & A & A \\
\hline S7.1 & 27 April 2003 & A & A & A & A & A & A & A & A \\
\hline S7.2 & 27 April 2003 & A & A & A & A & A & A & A & A \\
\hline S7.3 & 28 April 2003 & A & A & A & A & A & A & A & A \\
\hline S7.4 & 28 April 2003 & A & A & A & A & A & A & A & A \\
\hline S7.5 & 29 April 2003 & A & - & A & A & A & A & - & A \\
\hline S8.1 & 9 July 2003 & A & A & A & A & A & A & - & A \\
\hline S 8.2 & 9 July 2003 & A & A & A & A & A & A & - & A \\
\hline S8.3 & 10 July 2003 & A & A & A & A & A & A & - & A \\
\hline S8.4 & 10 July 2003 & A & A & A & A & A & A & - & A \\
\hline
\end{tabular}

was located near Iceland. In order to cross the tropopause on a high flight level we flew south to Monastir (Tunisia), reaching $33^{\circ} \mathrm{N}$ on 22 August where we expected to measure subtropical tropospheric air at high altitudes. On 23 August the northbound measurements were carried out. This is one of the two occasions when we chose to fly northwest instead of north, in order to reach deep into the stratosphere over Iceland where a low tropopause was predicted. The refuelling stop was in Keflavik (Iceland), and data are available up to a latitude of $64^{\circ} \mathrm{N}$. No GC data are available for the southbound flights and on the northbound flights water vapour data are missing. All other instruments worked nominally.

\subsubsection{SPURT-5: 17/18 October 2002}

The second autumn campaign took place after the passage of a low pressure system over northern Germany mostly in a region with a low tropopause. Again we flew southward on the first measurement day, refuelling in Sevilla (Spain) and reaching the southernmost latitude of $35^{\circ} \mathrm{N}$ on the flight back. The northbound leg went to Keflavik towards an isolated tropospheric air mass, and the northernmost datapoints are from $64^{\circ} \mathrm{N}$. This campaign has the most complete data set of all, as all instruments worked nominally during all flights. 
Table 4. SPURT flight coverage: Length of flight, maximum western longitude $\left({ }^{\circ} \mathrm{W}\right.$ are negative), maximum eastern longitude, minimum and maximum latitude reached by the Learjet. The maximum $\Theta$ and $\Delta \Theta$ levels, as well as the minimum $\mathrm{N}_{2} \mathrm{O}$ levels and the maximum $\mathrm{O}_{3}$ levels observed during the flights are also shown.

\begin{tabular}{|c|c|c|c|c|c|c|c|c|c|c|c|}
\hline Flight & date & $\begin{array}{l}\text { Flight Hours } \\
\text { hh:mm }\end{array}$ & $\begin{array}{l}\text { Lon west } \\
{\left[{ }^{\circ}\right]}\end{array}$ & $\begin{array}{l}\text { Lon east } \\
{\left[{ }^{\circ}\right]}\end{array}$ & $\begin{array}{l}\text { Lat min } \\
{\left[{ }^{\circ}\right]}\end{array}$ & $\begin{array}{l}\text { Lat max } \\
{\left[{ }^{\circ}\right]}\end{array}$ & $\begin{array}{l}\Theta \max \\
{[\mathrm{K}]}\end{array}$ & $\begin{array}{l}\Delta \Theta \max \\
{[\mathrm{K}]}\end{array}$ & $\begin{array}{l}\text { PV max } \\
{[\mathrm{PVU}]}\end{array}$ & $\begin{array}{l}\mathrm{O}_{3} \max \\
{[\mathrm{ppbv}]}\end{array}$ & $\begin{array}{l}\mathrm{N}_{2} \mathrm{O} \text { min } \\
{[\mathrm{ppb}]}\end{array}$ \\
\hline S1.1 & 10 Nov 2001 & 04:10 & -9.83 & 9.56 & 35.78 & 54.32 & 370.1 & 66.3 & 10.4 & 659.3 & 293.4 \\
\hline S1.2 & 10 Nov 2001 & 04:11 & -8.42 & 9.52 & 37.01 & 54.29 & 362.1 & 2.0 & 2.7 & 115.0 & 309.8 \\
\hline $\mathrm{S} 1.3$ & 11 Nov 2001 & 02:44 & 9.37 & 21.39 & 54.29 & 68.66 & 370.0 & 71.7 & 8.7 & 538.5 & 296.8 \\
\hline S1.4 & 11 Nov 2001 & 04:01 & 9.68 & 25.24 & 54.19 & 73.12 & 367.6 & 69.6 & 9.0 & 580.6 & 294.7 \\
\hline S2.1 & 17 Jan 2002 & 04:24 & -8.22 & 9.56 & 33.49 & 54.34 & 365.4 & 52.0 & 8.6 & 397.4 & 300.2 \\
\hline S2.2 & 17 Jan 2002 & 01:21 & -14.44 & -7.77 & 27.50 & 33.33 & 342.0 & 18.7 & 6.1 & 212.5 & 311.0 \\
\hline S2.3 & 18 Jan 2002 & $02: 27$ & -15.39 & -7.69 & 27.92 & 38.60 & 363.1 & 25.7 & 8.1 & 280.2 & 303.0 \\
\hline S2.4 & 18 Jan 2002 & $03: 25$ & -9.14 & 9.56 & 38.77 & 54.14 & 360.9 & 28.2 & 9.0 & 398.1 & 302.6 \\
\hline S2.5 & 19 Jan 2002 & $04: 27$ & 0.11 & 19.20 & 54.31 & 73.20 & 361.7 & 58.3 & 8.6 & 693.9 & 285.7 \\
\hline S2.6 & 19 Jan 2002 & 04:16 & 0.10 & 19.07 & 54.39 & 73.13 & 372.2 & 65.8 & 9.0 & 693.3 & 286.3 \\
\hline S3.1 & 16 Мау 2002 & 04:40 & -8.68 & 9.63 & 36.13 & 54.32 & 355.5 & 16.3 & 7.4 & 376.9 & 296.5 \\
\hline S3.2 & 16 May 2002 & 04:21 & -13.92 & 8.85 & 36.72 & 54.22 & 369.4 & 40.1 & 9.9 & 670.7 & 281.0 \\
\hline S3.3 & 17 May 2002 & 04:24 & 9.25 & 24.00 & 54.28 & 75.10 & 372.6 & 67.5 & 8.5 & 790.9 & 279.7 \\
\hline S3.4 & 17 May 2002 & 04:34 & 5.02 & 18.97 & 47.85 & 69.75 & 371.6 & 31.9 & 8.4 & 686.5 & 280.8 \\
\hline S4.1 & 22 Aug 2002 & 03:47 & 9.52 & 13.60 & 33.80 & 54.32 & 363.1 & 22.8 & 9.3 & 364.6 & 300.6 \\
\hline S4.2 & 22 Aug 2002 & $03: 26$ & 8.33 & 11.86 & 35.72 & 54.52 & 370.9 & 40.2 & 9.4 & 448.7 & 298.6 \\
\hline S4.3 & 23 Aug 2002 & 03:36 & -27.21 & 9.76 & 54.31 & 65.05 & 370.4 & 56.9 & 10.2 & 435.2 & 301.6 \\
\hline S4.4 & 23 Aug 2002 & 03:44 & -22.63 & 9.75 & 53.34 & 63.99 & 364.6 & 36.5 & 9.2 & 371.9 & 303.6 \\
\hline S5.1 & 17 Oct 2002 & 04:26 & -7.03 & 9.56 & 36.50 & 54.32 & 359.0 & 43.8 & 8.2 & 266.7 & 306.3 \\
\hline S5.2 & 17 Oct 2002 & $04: 25$ & -8.00 & 9.89 & 35.42 & 54.27 & 373.2 & 64.0 & 9.3 & 356.4 & 306.7 \\
\hline S5.3 & 18 Oct 2002 & 04:11 & -26.27 & 9.56 & 53.71 & 63.71 & 365.4 & 42.8 & 9.3 & 300.3 & 309.4 \\
\hline S5.4 & 18 Oct 2002 & 03:35 & -26.63 & 9.40 & 54.27 & 64.11 & 371.1 & 65.4 & 8.9 & 509.3 & 303.4 \\
\hline S6.1 & $15 \mathrm{Feb} 2003$ & 04:30 & -12.00 & 9.68 & 36.84 & 54.32 & 362.6 & 60.7 & 8.0 & 711.1 & 291.9 \\
\hline S6.2 & 15 Feb 2003 & 04:21 & -7.97 & 10.02 & 37.00 & 54.25 & 373.2 & 69.9 & 9.1 & 708.3 & 291.9 \\
\hline S6.3 & 16 Feb 2003 & $02: 50$ & 9.55 & 18.54 & 54.31 & 69.85 & 354.5 & 37.0 & 7.5 & 364.6 & 307.4 \\
\hline S6.4 & 16 Feb 2003 & 03:32 & 10.02 & 30.08 & 69.54 & 82.07 & 356.8 & 57.9 & 8.9 & 751.7 & 288.9 \\
\hline S6.5 & 16 Feb 2003 & 03:35 & 9.34 & 19.08 & 54.36 & 78.26 & 358.5 & 40.3 & 9.1 & 503.6 & 300.2 \\
\hline S7.1 & 27 April 2003 & 04:10 & 9.37 & 21.00 & 54.29 & 72.99 & 378.2 & 77.1 & 9.0 & 1049.9 & 263.2 \\
\hline S7.2 & 27 April 2003 & 04:38 & 8.43 & 20.35 & 49.99 & 70.53 & 373.6 & 60.7 & 8.2 & 736.4 & 285.2 \\
\hline S7.3 & 28 April 2003 & 04:29 & -10.39 & 9.54 & 38.50 & 54.31 & 355.6 & 27.9 & 7.1 & 645.1 & 289.1 \\
\hline S7.4 & 28 April 2003 & 04:16 & -10.19 & 13.44 & 37.95 & 54.51 & 366.7 & 43.3 & 9.3 & 657.9 & 288.4 \\
\hline S7.5 & 29 April 2003 & 04:12 & 9.42 & 15.60 & 53.27 & 66.09 & 367.1 & 47.9 & 8.3 & 746.1 & 284.9 \\
\hline S8.1 & 9 July 2003 & 03:56 & -8.70 & 9.56 & 35.88 & 54.32 & 363.8 & 34.0 & 9.3 & 430.4 & 300.1 \\
\hline S8.2 & 9 July 2003 & 04:20 & -8.05 & 9.55 & 35.87 & 54.47 & 365.3 & 32.4 & 8.0 & 469.4 & 299.3 \\
\hline S8.3 & 10 July 2003 & 03:57 & 9.30 & 21.82 & 54.29 & 73.25 & 372.2 & 66.2 & 10.9 & 559.0 & 292.8 \\
\hline S8.4 & 10 July 2003 & 04:05 & 6.54 & 21.75 & 49.90 & 69.69 & 367.2 & 34.7 & 10.1 & 567.6 & 291.1 \\
\hline
\end{tabular}

\subsubsection{SPURT-6: 15/16 February 2003}

During this campaign a very prominent high-pressure system was situated over middle and northern Europe and therefore the tropopause was generally quite high. The southbound flight to Faro (Portugal) took place on 15 February and reached $36^{\circ} \mathrm{N}$. The northbound leg on 16 February went to Longyearbyen (Spitsbergen) after a stop over in Tromsö (Norway). Data are available from as far north as $82^{\circ} \mathrm{N}$ and are the most poleward data available from SPURT. Only ECO (chemiluminescence) provided ozone data during the flight S6.4 and 6.5. All other data are complete.

\subsubsection{SPURT-7: 27-29 April 2003}

Europe was divided meteorologically into two broad regions during this campaign, a low pressure area towards the northwest (with a centre between Scotland and Iceland) and a high pressure area over the southern and eastern parts. The northbound flight took place on 27 April and reached $73^{\circ} \mathrm{N}$. The stopover airport was Kiruna (Sweden). The southbound flights took place on 28 April, with a stopover at Lisbon (Portugal) and southernmost datapoints around $38^{\circ} \mathrm{N}$. After this campaign, an extra flight for intercomparison of $\mathrm{NO}_{\mathrm{y}}$ instruments was added. This flight headed north on 29 April. As 
the $\mathrm{NO}_{\mathrm{y}}$ instrument used for the MOZAIC programme (VolzThomas et al., 2005) was added to the payload, the TDL and the $\mathrm{CO}_{2}$ instrument had to be removed for this extra flight.

\subsubsection{SPURT-8: 9-10 July 2003}

The final campaign took place in a region between a mature Icelandic Low and an anticyclone over Russia. Over southwestern Europe the ECMWF data show a richly structured tropopause with slowly evolving filaments of tropospheric and stratospheric air. The southern flights were performed on 9 July and the stopover airport was again Faro (Portugal) and data are available down to $36^{\circ} \mathrm{N}$. The northbound flights on 10 July reached $73^{\circ} \mathrm{N}$ with refuelling at Tromsö (Norway). Data from this campaign are complete, with the exception of $\mathrm{CO}_{2}$, which is not available.

\section{Data overview}

In the frame of the SPURT project a large number of data has been collected in the UT/LMS for a wide range of tracers. For many tracers (e.g. $\mathrm{N}_{2} \mathrm{O}, \mathrm{SF}_{6}, \mathrm{CO}_{2}$ ) the observed variabilities are very small. It should also be noted that the LMS is a dynamically very active region. Representing the data in classical co-ordinate systems does not show the features of the typical distributions. This is illustrated in Fig. 5, where the distribution of $\mathrm{N}_{2} \mathrm{O}$ measured during campaign $\mathrm{S} 8$ is plotted vs. pressure, potential temperature, potential vorticity and Theta above the local tropopause (note that the local tropopause is calculated form the ECMWF data). It is clearly visible that the complete range of $\mathrm{N}_{2} \mathrm{O}$ values observed is present at all pressures below about $250 \mathrm{hPa}$ and all potential temperatures above about $340 \mathrm{~K}$. A systematic structure is only clear when using PV or Theta above the local tropopause as vertical coordinates, i.e. vertical scales which hold some tropopause information. Therefore, in order to give an overview of the data collected during SPURT, the measurements of $\mathrm{N}_{2} \mathrm{O}, \mathrm{CO}, \mathrm{O}_{3}, \mathrm{SF}_{6}, \mathrm{CO}_{2}, \mathrm{H}_{2} \mathrm{O}$ and $\mathrm{NO}_{\mathrm{y}}$ will be presented in the equivalent latitude - potential temperature coordinate system, and grouped by season. Since the distributions of CFC- 12 and $\mathrm{CH}_{4}$ are very similar to those derived from $\mathrm{N}_{2} \mathrm{O}$, they will not be presented separately. For all distributions shown below, the data from the two campaigns in each season have been combined and binned on a $5^{\circ}$ equivalent latitude $/ 5 \mathrm{~K}$ potential temperature grid. A mean from all measurements inside each grid box was then calculated. In the case of $\mathrm{N}_{2} \mathrm{O}$ two instruments (TRISTAR and GhOST II) provided data, with different temporal resolutions and precisions, the GC GhOST II having a higher precision than the TDL TRISTAR. The mean values given for each box represents an average of TDL and GC data, each measurement point being weighted according to its precision (e.g. a single GHOST II observation with $0.5 \%$ precision would be weighted twice as heavily as a TRISTAR measurement point
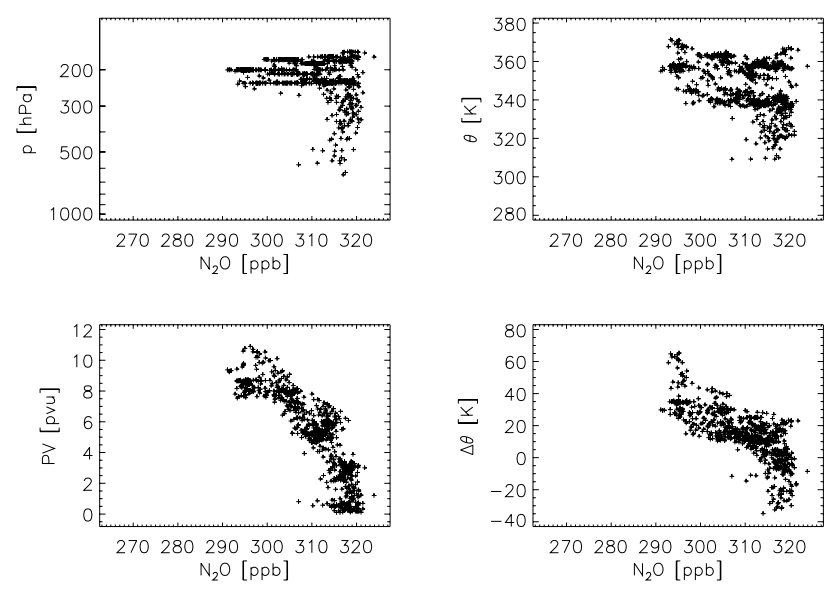

Fig. 5. Distribution of $\mathrm{N}_{2} \mathrm{O}$ derived from GhOST II measurements during campaign $\mathrm{S} 8$, as a function of different vertical scales. Only vertical scales including tropopause information (i.e. PV or $\Delta \Theta$ ) can reveal the systematic structure of the distribution, wheras scales like pressure (p) or $\Theta$ show a large scatter in the data

with $1 \%$ precision). In the case of $\mathrm{O}_{3}$ the data from the UV photometer JOE were used as these are available over the entire time frame of the project, with the exception of two flights during February 2003. For these flights the chemiluminescence measurements by the ECO instrument were used.

\subsection{Nitrous oxide $-\mathrm{N}_{2} \mathrm{O}$}

Nitrous oxide shows very uniform values in the troposphere (Fig. 6). For example during the campaigns in 2003 the GhOST II measured mean tropospheric $\mathrm{N}_{2} \mathrm{O}$ values between $318.3 \pm 1.5$ (1 sigma standard deviation) in February 2003 and $318.8 \pm 1.4 \mathrm{ppb}$ in July 2003. The standard deviations include the instrumental precisions, which is on the order of $1 \mathrm{ppb}$. These data agree very well with the values from the NOAA/CMDL network (e.g. Elkins et al., 1993, updated), which show $\mathrm{N}_{2} \mathrm{O}$ mixing ratios of $318.2 \pm 0.4 \mathrm{ppb}$ and $318.4 \pm 0.7 \mathrm{ppb}$ for the respective time periods. With the exception of the spring season, values very close to the tropospheric mean are observed up to $\mathrm{PV}$ values of 4 to 6PVU depending on season. The lowest $\mathrm{N}_{2} \mathrm{O}$ values are observed during spring. The minimum $\mathrm{N}_{2} \mathrm{O}$ value observed during SPURT was $263 \mathrm{ppb}$ during flight S7.1. during other spring time flights the lowest values were on the order of $280 \mathrm{ppb}$. The highest, i.e. most tropospheric values are found during autumn. During the autumn campaign SPURT1 in November 2001, the lowest $\mathrm{N}_{2} \mathrm{O}$ observations were around $294 \mathrm{ppb}$, and during the second autumn campaign (SPURT-5 in October 2002) no $\mathrm{N}_{2} \mathrm{O}$ values below $300 \mathrm{ppb}$ were observed. Note the similarity between the distributions observed during winter and summer and the tilt of the isopleths relative to isentropes. 

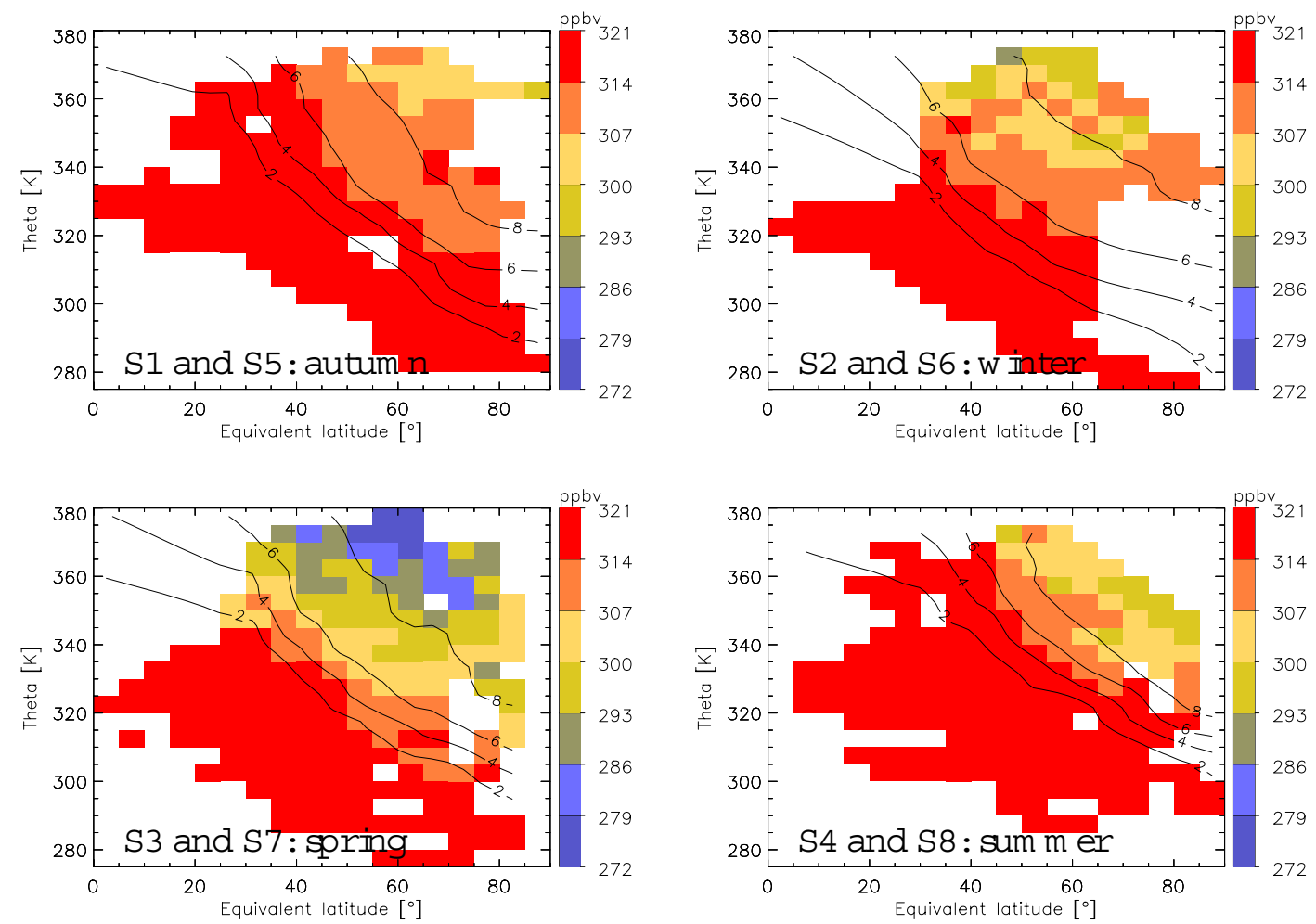

Fig. 6. Observed distribution of $\mathrm{N}_{2} \mathrm{O}$ sorted by season as function of equivalent latitude and potential temperature. Data are from the TDL TRISTAR and the GC GhOST II. The black lines represent different PV isopleths (2, 4, 6 and 8 PVU). The 2 PVU isopleth is often used as the dynamical tropopause.
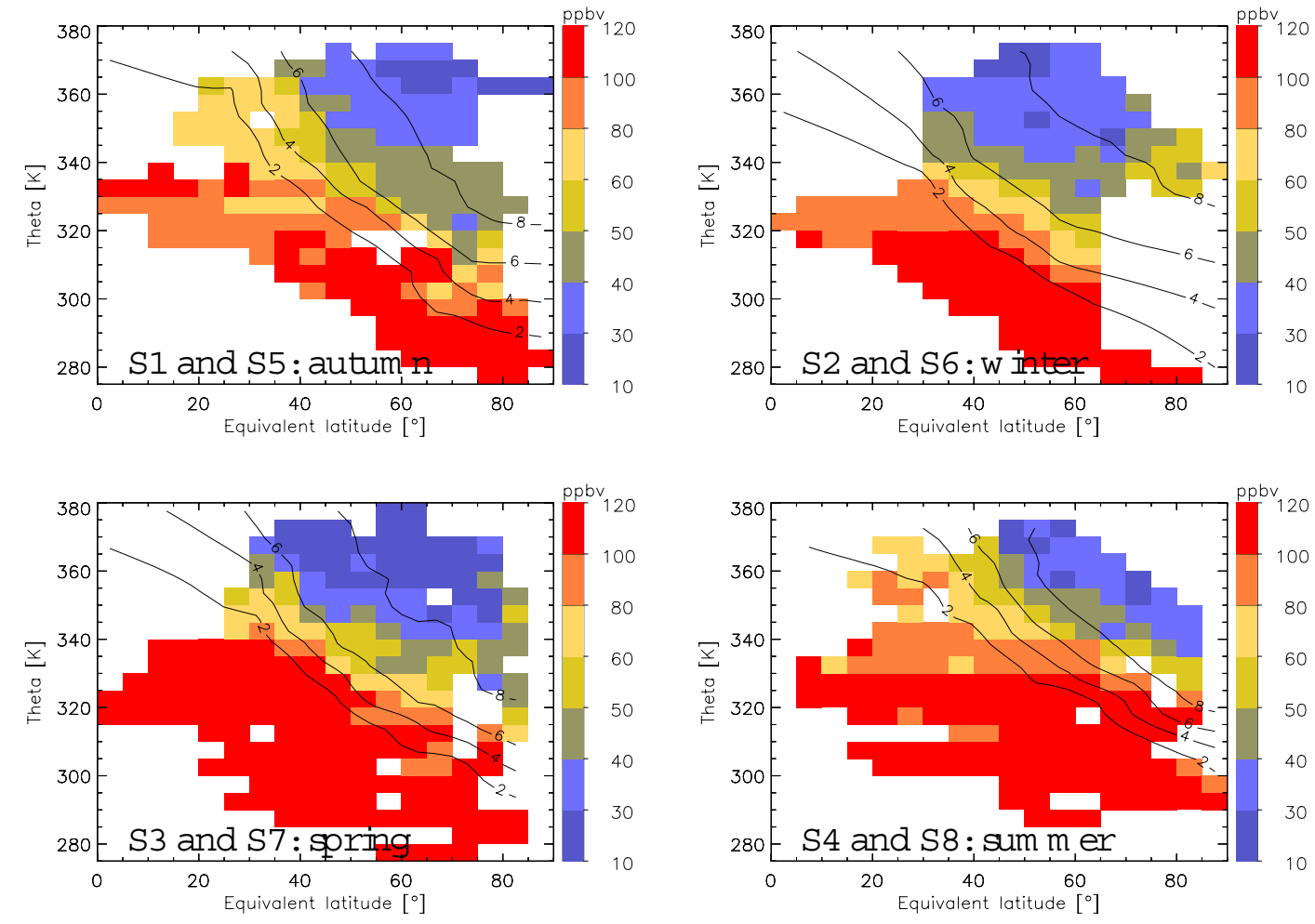

Fig. 7. As Fig. 6, but for CO. Data are from the TDL TRISTAR. 


\subsection{Carbon monoxide - $\mathrm{CO}$}

The distribution of $\mathrm{CO}$ derived from SPURT (Fig. 7) has been discussed previously by Hoor et al. (2004a, b). CO shows higher variability than $\mathrm{N}_{2} \mathrm{O}$ in the troposphere and a latitudinal gradient, with lower mean values in the upper troposphere at low latitudes. $\mathrm{CO}$ has a much shorter lifetime than e.g. $\mathrm{N}_{2} \mathrm{O}$, on the order of 3 months, but also has a stratospheric source from methane oxidation. In the background stratosphere typical values below $15 \mathrm{ppb}$ are expected. Such low mixing ratios are only observed far away from the tropopause in the overworld at altitudes exceeding the SPURT flight ceiling. Average values below $40 \mathrm{ppb}$ are only observed for PV $>6$ PVU, which is only the case at a distance of at least $\Delta \theta=20$ to $30 \mathrm{~K}$ above the local tropopause.

\subsection{Ozone $-\mathrm{O}_{3}$}

Ozone has its main sources in the stratosphere. Ozone is not an inert tracer in the lowermost stratosphere, like e.g. $\mathrm{N}_{2} \mathrm{O}$. Yet the chemical lifetime of the odd oxygen $\left(\mathrm{O}_{\mathrm{x}}\right)$ - family is well above 1 year in the lower stratosphere below $20 \mathrm{~km}$ (see e.g. Brasseur and Solomon, 1986). Therefore the distribution of ozone in the lowermost stratosphere is dominated by transport rather then chemistry. The seasonal changes of upper tropospheric ozone are not resolved in the figures shown below. Note, however, that the SPURT data show $\mathrm{O}_{3}$ values in the tropopause region (2-3 PVU) in spring and summer being about $60 \%$ higher than corresponding values in autumn and winter (see also Hegglin et al., 2005a; Krebsbach et al., 2005a). This seasonal variation is generally smaller at 5$6 \mathrm{~km}$, which is considered to be representative of the free troposphere, since it is rather weakly influenced by small scale anomalies of the tropopause height and by local emissions of $\mathrm{O}_{3}$ precursors that generally take place in the boundary layer (Fischer et al., 2005). As in the case of $\mathrm{N}_{2} \mathrm{O}$ the most stratospheric values are observed in the upper part of the LMS during spring, where maximum values close to $1000 \mathrm{ppbv}$ were observed (Fig. 8). Much lower values were measured during the other seasons. The ozone isopleths very closely follow the PV isolines. During summer and even more pronounced during autumn, a region of rather low ozone is observed in the lowermost stratosphere up to PV values of 4 to $6 \mathrm{PVU}$ between about 20 and 40 degrees of equivalent latitude.

\subsection{Sulfur hexafluoride $-\mathrm{SF}_{6}$}

Sulfurhexafluoride is an extremely long lived atmospheric trace gas, which has its only sink in the mesosphere. In contrast to most of the other tracers measured during SPURT, the vertical gradient observed in $\mathrm{SF}_{6}$ is not caused by chemistry but is rather due to the time lag with which the tropospheric increase propagates into the LMS. It is therefore not possible to combine $\mathrm{SF}_{6}$ data from different years without accounting for the long-term trend. Therefore, we present the $\mathrm{SF}_{6}$ data from the second annual cycle, based on the SPURT campaigns 5 to 8 (Fig. 9), which provide a complete $\mathrm{SF}_{6}$ data set. Again, the air with the strongest stratospheric influence is observed during spring, where the lowest mixing ratios of $\mathrm{SF}_{6}$ were found. As with many other tracers, the distribution of $\mathrm{SF}_{6}$ closely follows the $\mathrm{PV}$ isolines. Note that $\mathrm{SF}_{6}$ increases in the troposphere at a rate of about 4 to $5 \%$ per year (i.e. about $0.1 \mathrm{ppt}$ per year). This is reflected by the higher values of $\mathrm{SF}_{6}$ in the summer (the SPURT- 8 campaign took place in July 2003) than in autumn (SPURT-5 was carried out in October 2002).

\subsection{Carbon dioxide $-\mathrm{CO}_{2}$}

Similar to $\mathrm{SF}_{6}, \mathrm{CO}_{2}$ also has a sufficiently long atmospheric lifetime to reveal its long-term trend in the stratosphere. In addition, $\mathrm{CO}_{2}$ has a pronounced seasonal cycle in the troposphere, due to the uptake and release by vegetation. The distribution of $\mathrm{CO}_{2}$ (Fig. 10) therefore shows a unique pattern. As is the case of $\mathrm{SF}_{6}$, only one seasonal cycle is shown, as the long term increase could otherwise mask the seasonal variability. Since the data set for the first seasonal cycle is more complete, we present the results from SPURT-1 to 4. During SPURT-1 in Autumn 2001 very little variability of $\mathrm{CO}_{2}$ was observed throughout the LMS. During winter and spring, the $\mathrm{CO}_{2}$ values in the LMS are mostly below the tropospheric values. On the contrary, during summer, $\mathrm{CO}_{2}$ was higher in the stratosphere than in the troposphere. This particular behavior of $\mathrm{CO}_{2}$ was described by Hoor et al. (2004b), who suggested that a large part of the air in the lowermost stratosphere with elevated $\mathrm{CO}_{2}$ (as well as $\mathrm{CO}>15 \mathrm{ppb}$ ) was caused by relatively fast transport from the upper tropical troposphere, where tropospheric summertime $\mathrm{CO}_{2}$ values are higher than in the mid latitude during the same period.

\subsection{Reactive nitrogen $-\mathrm{NO}_{\mathrm{y}}$}

Reactive nitrogen $\left(\mathrm{NO}_{\mathrm{y}}\right)$ is the sum of all reactive nitrogen species with an oxidation state higher than one. The production of reactive nitrogen is initiated in the stratosphere due to reaction of $\mathrm{N}_{2} \mathrm{O}$ with $\mathrm{O}(1 \mathrm{D})$. In addition, sources due to lightning, deep convective injection of planetary boundary layer air, and air traffic emissions may influence the budget of $\mathrm{NO}_{\mathrm{y}}$ in the UT/LMS. Figure 11 shows the observed distributions of $\mathrm{NO}_{\mathrm{y}}$. As the scale is reversed (i.e. the blue colours show the highest values) with respect to Fig. $5\left(\mathrm{~N}_{2} \mathrm{O}\right.$ distribution), the distributions look very similar. The highest values of $\mathrm{NO}_{\mathrm{y}}$ are observed during spring in the highest part of the LMS, again indicating the strongest stratospheric influence during this time of the year. Conversely, the summer and autumn distributions reveal significant influence of transport from the troposphere. A detailed discussion of the observed $\mathrm{NO}_{\mathrm{y}}$ tracer distributions and implications for the origin of air masses in the lowermost stratosphere as obtained from tracer-tracer correlations is given by Hegglin et al. (2005a). 

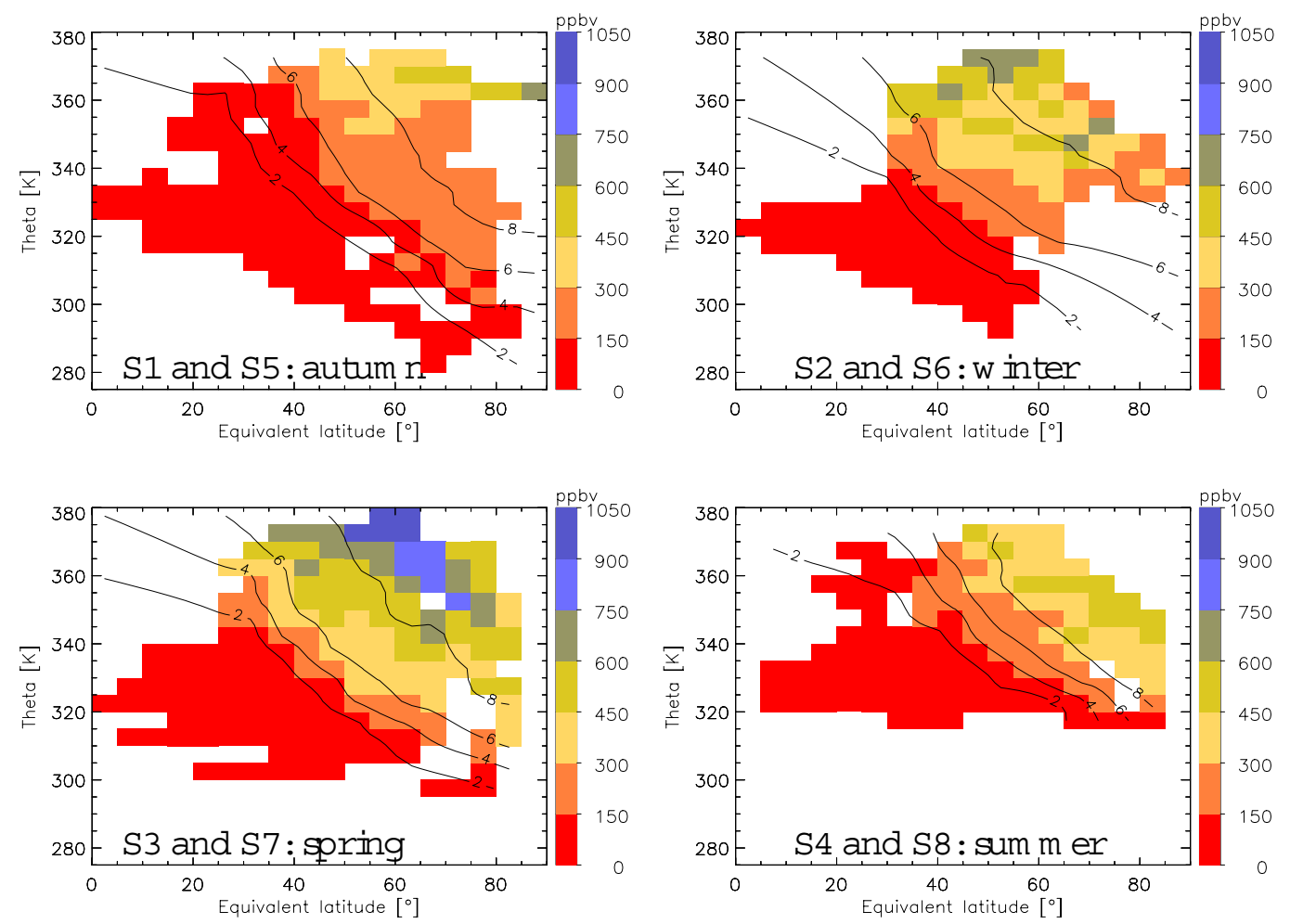

Fig. 8. As Fig. 6, but for $\mathrm{O}_{3}$. Data are from the UV photometer JOE and partly from the chemiluminescence instrument ECO.
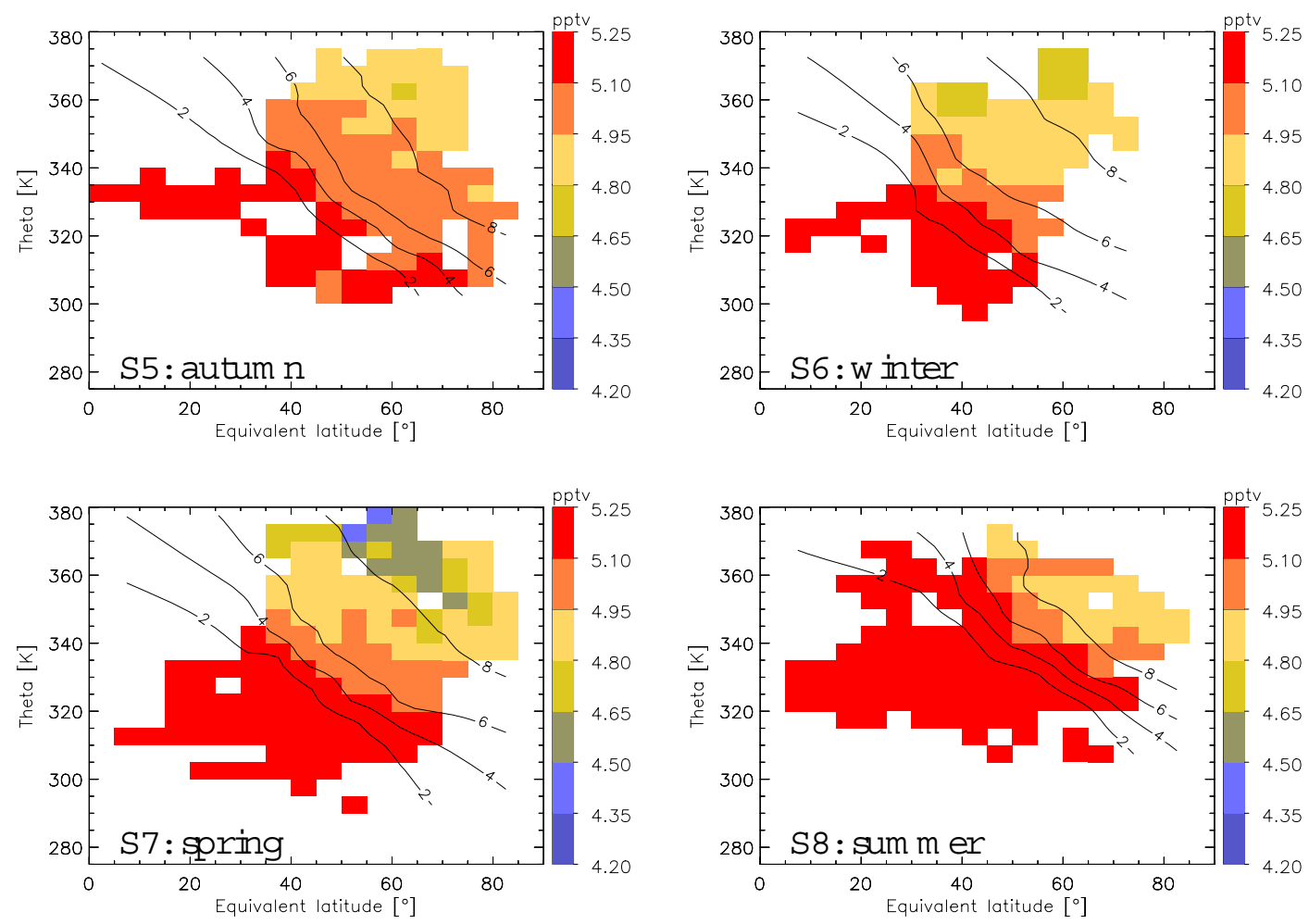

Fig. 9. As Fig. 6, but for $\mathrm{SF}_{6}$. Only one seasonal cycle is included. Data are from the GC GhOST II. 

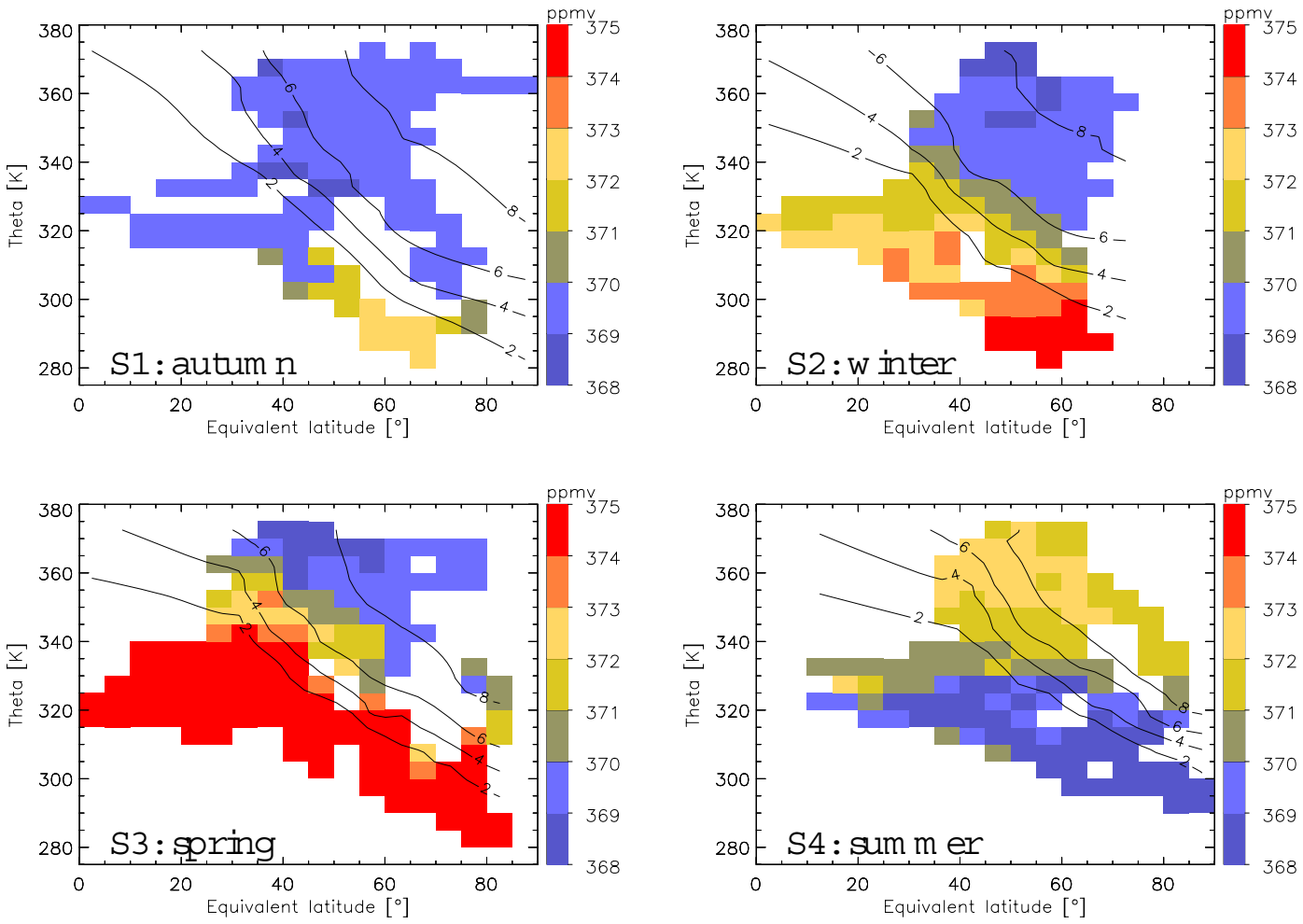

Fig. 10. As Fig. 6, but for $\mathrm{CO}_{2}$. Only one seasonal cycle is included. Data are from the non-dispersive $\mathrm{IR}^{\mathrm{CO}_{2}}$ analyzer FABLE.
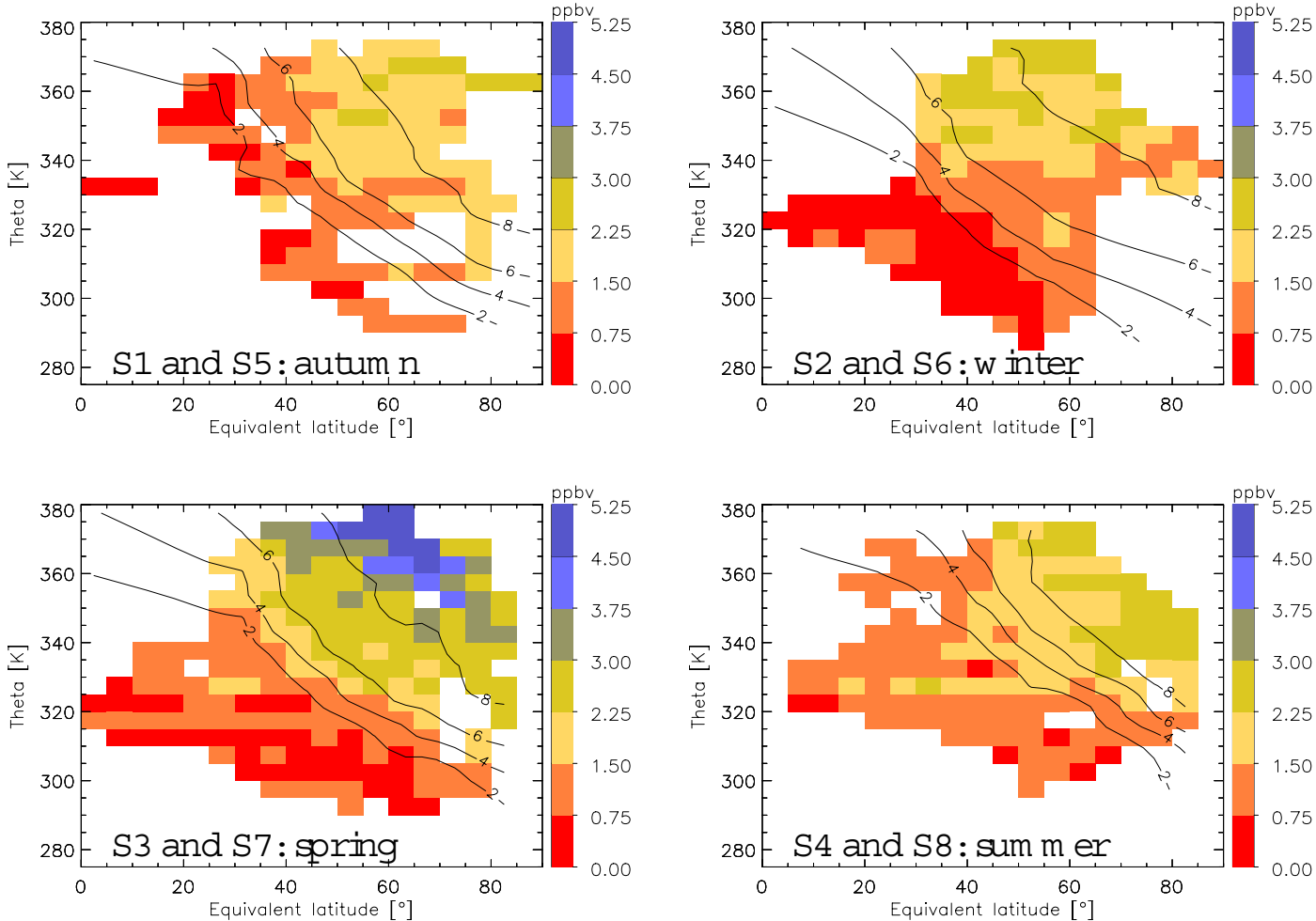

Fig. 11. As Fig. 6, but for $\mathrm{NO}_{y}$. Data are from the chemiluminescence instrument $\mathrm{ECO}$. 

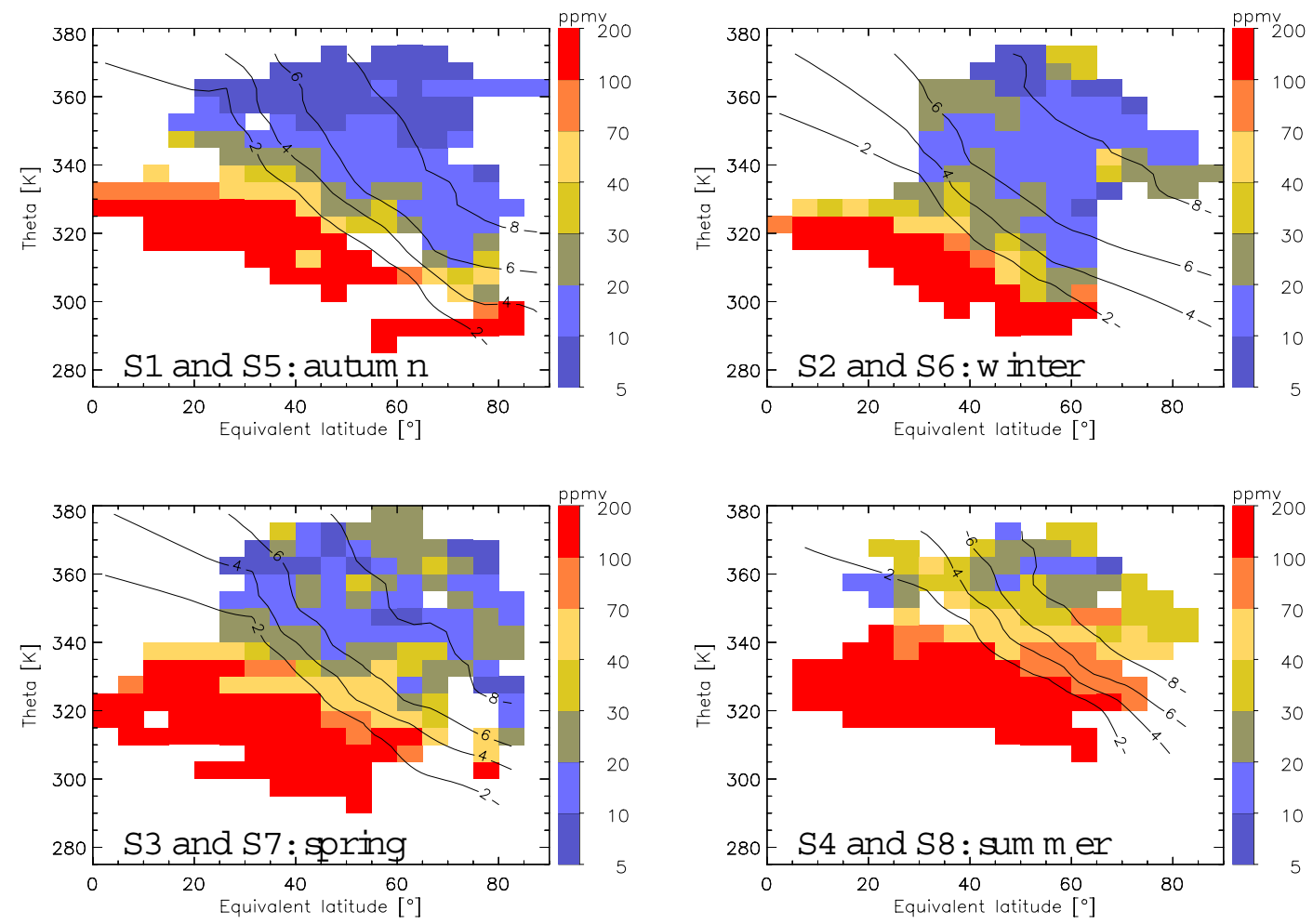

Fig. 12. As Fig. 6, but for $\mathrm{H}_{2} \mathrm{O}$. Data are obtained using the Lyman- $\alpha$ hygrometer FISH.

\subsection{Total water $-\mathrm{H}_{2} \mathrm{O}$}

Water is a tracer which is strongly influenced by freezedrying during the transport into the LMS. The highest mixing ratios of $\mathrm{H}_{2} \mathrm{O}$ are observed during summer and the lowest values during autumn (Fig. 12). This seasonality is in accordance with other observations of $\mathrm{H}_{2} \mathrm{O}$ in the LMS (Krebsbach et al., 2005 $b^{1}$ and references therein) but differs clearly from other tracers observed during SPURT, which show the most pronounced tropospheric influence a few months later. The difference must be explained by the different mechanisms controlling water vapour in the LMS and its large gradients at the tropopause which make $\mathrm{H}_{2} \mathrm{O}$ a very sensitive indicator for cross-tropopause transport. During the transit from summer to autumn very dry air appears to be transported into the lowermost stratosphere. Water vapour is also the tracer which shows most significantly the tropospheric influence even at rather large distances from the local tropopause. One reason is again that $\mathrm{H}_{2} \mathrm{O}$ concentrations have by far the largest contrast between tropospheric and stratospheric values. Further, there are practically no sinks of water vapour in the LMS except freeze-drying at the coldest point which is located near the tropopause. Thus, once humid air masses have entered the LMS, they can only be diluted with drier stratospheric background air and be removed from the LMS by transport. Finally, the efficiency of freeze-drying at the tropopause shows a strong seasonal cycle and latitudinal dependence, overlaid by episodic short-term variability. Detailed investigations of $\mathrm{H}_{2} \mathrm{O}$ transport across the extratropical tropopause and its seasonality are given in specific studies (Krebsbach et al., 2005a, $\mathrm{b}^{1}$ ).

\section{Conclusions and outlook}

SPURT has provided a comprehensive data set of trace gases for the lowermost stratosphere (LMS) in the Northern Hemisphere. This data set is of high quality and contains a number of important trace gases with different lifetimes and different source/sink characteristics. Species with different lifetimes can give information on different chemical and transport processes (see e.g. Tuck et al., 2004). The SPURT data set also provides an ideal basis for studies of meso- and small-scale troposphere-to-stratosphere transport processes (e.g. isentropic or associated with deep convection) and their impact on lowermost stratospheric trace gas distributions. The high quality of the data set is evident from the intercomparison between the simultaneously measured $\mathrm{N}_{2} \mathrm{O}$ (by GC and TDL) and $\mathrm{O}_{3}$ (by UV absorption and chemiluminescence). Both intercomparisons show an agreement which is better than the stated combined uncertainties of the instruments over the entire range of values. In several studies we show, that by using an adequate coordinate system (potential temperature and equivalent latitude) much of the natural variability, which is due to reversible synoptic-scale processes, can be removed from the data (e.g. Hoor et al., 2004a, b; Hegglin et al., 2005a; Krebsbach et al., 2005a, b ${ }^{1}$ ). 
Presenting the data in this coordinate system, clear seasonalities in the lowermost stratosphere are observed. Over the course of the winter and into spring, the LMS is filled up with air of marked stratospheric character, which has comparatively low mixing ratios of $\mathrm{N}_{2} \mathrm{O}, \mathrm{SF}_{6}, \mathrm{CO}$, and $\mathrm{H}_{2} \mathrm{O}$ but relatively high mixing ratios of ozone and $\mathrm{NO}_{\mathrm{y}}$. This air is replaced over the summer and into autumn by air of more tropospheric character, having higher mixing ratios of $\mathrm{N}_{2} \mathrm{O}$ and $\mathrm{SF}_{6}$ and lower mixing ratios of $\mathrm{NO}_{\mathrm{y}}$ and ozone. Within the SPURT project the driest air in the lowermost stratosphere was observed during autumn and winter, whereas the moistest air was present in summer. The SPURT observations reveal a tropopause following transition layer (Hoor et al., 2004b, 2005; Hegglin et al., 2005b; Krebsbach et al., $2005 b^{1}$ ), showing trace gas mixing ratios intermediate between typical tropospheric and stratospheric values. This layer shows seasonal variability and slightly varying thickness, depending on the trace gases used for its determination and the elapsed time since the mixing occurs (e.g. Hoor et al., 2004a, 2005; Krebsbach et al., 2005 ${ }^{1}$ ). The SPURT data confirm that the LMS is a mixture of air from the overworld and from the extratropical upper troposphere (e.g. Hoor et al., 2004b; Hegglin et al., 2005b), as is also assumed in some budget studies (e.g. Ray et al., 1999). However, another important pathway influencing the lowermost stratosphere is fast transport of upper tropospheric air from the tropics, as evidenced in the seasonal cycle of $\mathrm{CO}_{2}$ or of tracer-tracer correlations (e.g. Hoor et al., 2004b, 2005; Bönisch et al., 2005² Hegglin et al., 2005a). Isentropic transport (e.g. through exchange near the sub-tropical tropopause break) or transport via the tropically controlled transition layer (Rosenlof et al., 1997) in the extratropical lower stratosphere could explain these observations. Budget studies allow investigating the seasonality of the influence of different source regions on the LMS (e.g. Bönisch et al., 2005²), indicating that depending on season $30-50 \%$ of the air in the LMS originate at the tropical tropopause (Hoor et al., 2005).

Accompanying modelling work focuses on transport of air into the lowermost stratosphere, using the SPURT observations to compare the model results with atmospheric reality. The SPURT data set is ideally suited for the initialisation and systematic evaluations of models, in particular for transport studies and budget investigations in the UT/LMS on regional up to hemispherical scales, and for investigations of seasonal variability. Several studies using a simple 2-D model (Hegglin et al., 2005a) up to full 3-D Lagrangian CTM (CLaMS) have been carried out or are under preparation (Günther et al., $2005^{3}$; Pan et al., 2006). SPURT data have also been applied

\footnotetext{
${ }^{2}$ Bönisch, H., Engel, A., Schmidt, U., et al.: A budget study of air mass origin in the lowermost stratosphere based on in-situ observations of $\mathrm{CO}_{2}$ and $\mathrm{SF}_{6}$ during SPURT, in preparation, 2005.

${ }^{3}$ Günther, G., Konopka, P., Krebsbach, M., and Schiller, C.: The quantification of water vapor transport in the tropopause region using a lagrangian model, in preparation, 2005.
}

to assimilation techniques (Elbern and Strunk, 2005). Case studies of atmospheric transport in the UT/LMS for specific SPURT missions are carried-out using e.g. Reverse Domain Filling (RDF) techniques or a parameterised convective influence analyses (e.g. Hegglin et al., 2004; Krebsbach, 2005). Detailed investigation of backward trajectories together with the trace gas observations reveal important aspects for instance of TST events. Finally, the SPURT campaign spurred more theoretical work on fundamental properties of tracer advection in the extratropical tropopause region (Wirth et al., 2005) and on the sharpness of the extratropical tropopause during baroclinic development (Szabo and Wirth, 2006 ${ }^{4}$ ).

Acknowledgements. We would like to thank the Gesellschaft für Flugzieldarstellung (GFD) for the excellent co-operation and support during the aircraft campaigns. Funding of the project under the AFO 2000 programme of the German Ministry for Education and Research (BMBF) is gratefully acknowledged.

The Institute for Atmospheric and Climate Science (ETH) thanks the Swiss National Fund for its support of the $\mathrm{NO}_{\mathrm{y}^{-}}$, NO-, and $\mathrm{O}_{3}$-instrumentation and MeteoSwiss for granting access to the ECMWF data.

Edited by: P. Haynes

\section{References}

Appenzeller, C., Holton, J. R., and Rosenlof, K. H.: Seasonal variation of mass transport across the tropopause, J. Geophys. Res., 101(D10), 15 071-15 078, doi:10.1029/96JD00821, 1996.

Boering, K. A., Daube, B. C., Wofsy, S. C., Loewenstein, M., Podolske, J. R., and Keim, E. R.: Tracer-tracer relationships and lower stratospheric dynamics: $\mathrm{CO}_{2}$ and $\mathrm{N}_{2} \mathrm{O}$ correlations during SPADE, Geophys. Res. Lett., 21(23), 2567-2570, 1994

Boering, K. A., Wofsy, S. C., Daube, B. C., Schneider, H. R., Loewenstein, M., and Podolske, J. R.: Stratospheric mean ages and transport rates from observations of carbon-dioxide and nitrous-oxide, Science, 274, 1340-1343, 1996.

Brasseur, G. and Solomon, S.: Aeronomy of the Middle Atmosphere, Second Edition, D. Reidel Publishing Company, Dordrecht, 1986.

Brenninkmeijer, C. A. M., Crutzen, P. J., Fischer, H., Gusten, H., Hans, W. Heinrich, G., Heintzenberg, J., Hermann, M., Immelmann, T., Kersting, D., Maiss, M., Nolle, M., Pitscheider, A., Pohlkamp, H., Scharffe, D., Specht, K., and Wiedensohler, A.: CARIBIC - Civil aircraft for global measurement of trace gases and aerosols in the tropopause region, J. Atmos. Ocean. Technol., 16(10), 1373-1383, 1999.

Brunner, D., Staehelin, J., Jeker, D., Wernli, H., and Schumann, U.: Nitrogen oxides and ozone in the tropopause region of the Northern Hemisphere: Measurements from commercial aircraft in 1995/96 and 1997, J. Geophys. Res., 106, 27 673-27 699, 2001.

\footnotetext{
${ }^{4}$ Szabo, T. and Wirth, V.: The Sharpness of the Extratropical Tropopause in Baroclinic Life Cycle Experiments, in preparation, 2006.
} 
Bujok, O., Tan, V., Klein, E., Nopper, R., Bauer, R., Engel, A., Gerhards, M.-T., Afchine, A., McKenna, D. S., Schmidt, U., Wienhold, F. G., and Fischer, H.: GHOST - a novel airborne gas chromatograph for in situ measurements of long-lived tracers in the lower stratosphere: Method and Applications, J. Atmos. Chem., 39, 37-64, 2001.

Dethof, A., O'Neill, A., and Slingo, J.: Quantification of the isentropic mass transport across the dynamical tropopause, J. Geophys. Res., 105(D10), 12 279-12 293, 2000.

Elbern, H. and Strunk, A.: Tracer Analyses for Tropospheric Field Experiments by Chemical 4Dimensional Variational Data Assimilation (SATEC4D), AFO newsletter 10, 2005.

Elkins, J. W., Thompson, T. M., Swanson, T. H., Butler, J. H., Hall, B. D., Cummings, S. O., Fisher, D. A., and Raffo, A. G.: Decrease in the growth rates of atmospheric chlorofluorocarbons 11 and 12, Nature, 364, 780-783, 1993.

Fahey, D., Eubank, C., Huebler, G., and Fehsenfeld, F.: Evaluation of a catalytic reduction technique for the measurement of total reactive odd-nitrogen $\mathrm{NO}_{\mathrm{y}}$ in the atmosphere, J. Atmos. Chem., 3, 435-468, 1985.

Fioletov, V. E., Bodeker, G. E., Miller, A. J., McPeters, R. D., and Stolarski, R.: Global and zonal total ozone variations estimated from ground-based and satellite measurements: 1964-2000, J. Geophys. Res., 107, 4647, doi:10.1029/2001JD001350, 2002.

Fischer, H., Wienhold, F. G., Hoor, P., Bujok, O., Schiller, C., Siegmund, P., Ambaum, M., Scheeren, H. A., and Lelieveld, J.: Tracer correlations in the northern high latitude lowermost stratosphere: Influence of cross-tropopause mass exchange, Geophys. Res. Lett., 27(1), 97-100, 2000.

Fischer, H., Lawrence, M. G., Gurk, C., Hoor, P., Lelieveld, J., Hegglin, M. I., Brunner, D., and Schiller, C.: Model simulations and aircraft measurements of vertical, seasonal and latitudinal $\mathrm{O}_{3}$ and CO distributions over Europe, Atmos. Chem. Phys. Discuss., 5, 9065-9096, 2005,

\section{SRef-ID: 1680-7375/acpd/2005-5-9065.}

Forster, P. M. D. and Shine, K. P.: Radiative forcing and temperature trends from stratospheric ozone changes, J. Geophys. Res., 102(D9), 10 841-10 855, 1997.

Fromm, M., Alfred, J., Hoppel, K., Hornstein, J., Bevilacqua, R., Shettle, E., Servranckx, R., Li, Z. and Stocks, B.: Observations of boreal forest fire smoke in the stratosphere by POAM III, SAGE II, and lidar in 1998, Geophys. Res. Lett., 27(9), 14071410, 2000.

Gurk, C.: Untersuchungen zur Verteilung von Kohlendioxid in der Tropopausenregion, Diploma thesis, Johannes-Gutenberg University, Mainz, 2003.

Hegglin, M. I., Brunner, D., Wernli, H., Schwierz, C., Martius, O., Krebsbach, M., Schiller, C., Spelten, N., Hoor, P., Fischer, H., Parchatka, U., Weers, U., Staehelin, J., and Peter, Th.: Tracing troposphere-to-stratosphere transport within a mid-latitude deep convective system, Atmos. Chem. Phys., 4, 741-756, 2004,

SRef-ID: 1680-7324/acp/2004-4-741.

Hegglin, M. I.: Airborne $\mathrm{NO}_{\mathrm{y}^{-}}$, $\mathrm{NO}-$ and $\mathrm{O}_{3}$-measurements during SPURT: Implications for atmospheric transport, $\mathrm{PhD}$ thesis ETH Zurich, URL http://e-collection.ethbib.ethz.ch/cgi-bin/ show.pl?type $=$ diss\&nr=15553, 2004.

Hegglin, M. I., Brunner, D., Peter, T., Hoor, P., Fischer, H., Staehelin, J., Krebsbach, M., Schiller, C., Parchatka, U., and Weers, U.: Measurements of $\mathrm{NO}, \mathrm{NO}_{\mathrm{y}}, \mathrm{N}_{2} \mathrm{O}$, and $\mathrm{O}_{3}$ during SPURT:
Seasonal distributions and correlations in the lowermost stratosphere, Atmos. Chem. Phys. Discuss., 5, 8649-8688, 2005a,

SRef-ID: 1680-7375/acpd/2005-5-8649.

Hegglin, M. I., Brunner, D., Peter, T., Wirth, V., Staehelin, J., Hoor, P., and Fischer, H.: Determination of eddy diffusivity in the lowermost stratosphere, Geophys. Res. Lett., 32, L13812, doi:10.1029/2005GL022495, 2005b.

Hintsa, E. J., Weinstock, E. M., Dessler, A. E., Anderson, J. G., Loewenstein, M., and Podolske, J. R.: SPADE $\mathrm{H}_{2} \mathrm{O}$ measurements and the seasonal cycle of stratospheric water vapor, Geophys. Res. Lett., 21(23), 2559-2562, doi:10.1029/94GL01279, 1994.

Hintsa, E. J., Boering, K. A., Weinstock, E. M., et al.: Troposphereto-stratosphere transport in the lowermost stratosphere from measurements of $\mathrm{H}_{2} \mathrm{O}, \mathrm{CO}_{2}, \mathrm{~N}_{2} \mathrm{O}$ and $\mathrm{O}_{3}$, Geophys. Res. Lett., 25(14), 2655-2658, 1998.

Holton, J. R., Haynes, P. H., McIntyre, M. E., Douglass, A. R., Rood, R. B., and Pfister, L.: Stratosphere-troposphere exchange, Rev. Geophys., 33(4), 403-440, doi:10.1029/95RG02097, 1995.

Hoor, P., Fischer, H., Wong, S., Engel, A., and Wetter, T.: Intercomparison of airborne $\mathrm{N}_{2} \mathrm{O}$ observations using tunable diode laser absorption spectroscopy and in situ gas chromatography, Proceedings of the SPIE conference, Denver, Colorado, 19-20 July, 1999.

Hoor, P., Fischer, H., Lange, L., Lelieveld, J., and Brunner, D.: Seasonal variations of a mixing layer in the lowermost stratosphere as identified by the $\mathrm{CO}-\mathrm{O}_{3}$ correlation from in situ measurements, J. Geophys. Res., 107(D5), 4044, doi:10.1029/2000JD000289, 2002.

Hoor, P., Bönisch, H., Brunner, D., Engel, A., Fischer, H., Gurk, C., Günther, G., Hegglin, M., Krebsbach, M., Maser, R., Peter, T., Schiller, C., Schmidt, U., Spelten, N., Wernli, H., and Wirth, V.: New insights into upward transport across the extratropical tropopause derived from extensive in situ measurements during the SPURT project, SPARC Newsletter, 22, 2004a.

Hoor, P., Gurk, C., Brunner, D., Hegglin, M. I., Wernli, H., and Fischer, H.: Seasonality and extent of extratropical TST derived from in-situ CO measurements during SPURT, Atmos. Chem. Phys., 4, 1427-1442, 2004b,

SRef-ID: 1680-7324/acp/2004-4-1427.

Hoor, P., Fischer, H., and Lelieveld, J.: Tropical and extratropical tropospheric air in the lowermost stratosphere over Europe: A CO-based budget, Geophys. Res., Lett., 32, L07802, doi:10.1029/2004GL022018, 2005.

Hoskins, B. J., McIntyre, M. E., and Robertson, A. W.: On the use and significance of isentropic potential vorticity maps, Quart. J. Roy. Meteor. Soc., 111, 877-946, 1985.

Kormann, R., Fischer, H., Gurk, C., Helleis, F., Klüpfel, T., Kowalski, K., Königstedt, R., Parchatka, U., and Wagner, V.: Application of a multi-laser tunable diode laser absorption spectrometer for atmospheric trace gas measurements at sub-ppbv levels, Spectrochimica Acta, Part A, 58, 2489-2498, 2002.

Krebsbach, M.: Trace gas transport in the UT/LS, PhD thesis University Wuppertal, WUB-DIS 2005-03, 2005.

Krebsbach, M., Brunner, D., Günther, G., Hegglin, M., Maser, R., Mottaghy, D., Riese, M., Spelten, N., Wernli, H., and Schiller, C.: Seasonal cycles and variability of $\mathrm{H}_{2} \mathrm{O}$ and $\mathrm{O}_{3}$ in the UT/LMS during SPURT, Atmos. Chem. Phys. Discuss., 5, 7247-7282, 2005a, 
SRef-ID: 1680-7375/acpd/2005-5-7247.

Lacis, A. A., Wuebbles, D. J., and Logan, J. A.: Radiative forcing of climate by changes in the vertical distribution of ozone, J. Geophys. Res., 95, 9971-9981, 1990.

Lange, L., Fischer, H., Parchatka, U., Gurk, C., Zenker, T., and Harris, G.: Characterization and application of an externally mounted catalytic converter for aircraft measurements of $\mathrm{NO}_{\mathrm{y}}$, Rev. Sc. Instrum., 73, 3051-3057, 2002.

Logan, J. A., Megretskaia, I. A., Miller, A. J., et al.: Trends in the vertical distribution of ozone: A comparison of two analyses of ozonesonde data, J. Geophys. Res., 104, 26373-26399, 1999.

Marenco, A., Thouret, V., Nédélec, P., et al.: Measurement of ozone and water vapor by Airbus in-service aircraft: The MOZAIC airborne program, An overview, J. Geophys. Res., 103, 25631 $25642,1998$.

Montzka, S. A., Butler, J. H., Myers, R. C., Thompson, T. M., Swanson, T. H., Clarke, S. D., Lock, L. T., and Elkins, J. W.: Decline in the tropospheric abundance of halogen from halocarbons: implications for stratospheric ozone depletion, Science, 272, 1318-1322, 1996.

Mote, P. W., Rosenlof, K. H., McINtyre, M. E., et al.: An atmospheric tape recorder: the impact of tropical tropopause temperatures on stratospheric water vapor, J. Geophys. Res., 101, 39894006, 1996.

Mottaghy, D.: Aufbau, Charakterisierung und Validierung eines in-situ Instrumentes zur Messung von Ozon in der oberen Troposphäre und unteren Stratosphäre, Diploma thesis RWTH Aachen, 2001.

Paetz, H. W., Volz-Thomas, A., Hegglin, M. I., Brunner, D., Fischer, $\mathrm{H}$., and Schmidt, U.: In-situ comparison of the $\mathrm{NO}_{\mathrm{y}}$ instruments flown in MOZAIC and SPURT, Atmos. Chem. Phys. Discuss., 6, 649-671, 2006,

SRef-ID: 1680-7375/acpd/2006-6-649.

Pan, L. L., Hintsa, E. J., Stone, E. M., Weinstock, E. M., and Randel, W. J.: The seasonal cycle of water vapor and saturation vapor mixing ratio in the extratropical lowermost stratosphere, J. Geophys. Res., 105(D21), 26 519-26 530, doi:10.1029/2000JD900401, 2000.

Pan, L. L., Konopka, P., and Browell, E.: Observations and Model Simulations of Mixing near the Extratropical Tropopause, J. Geophys. Res., in press, 2006.

Ray, E. A., Moore, F. L., Elkins, J. W., Dutton, G. S., Fahey, D. W., Vömel, H., Oltmans, S. J., and Rosenlof, K. H.: Transport into the Northern Hemisphere lowermost stratosphere revealed by in situ tracer measurements, J. Geophys. Res., 104(D21), 26565 26580, doi:10.1029/1999JD900323, 1999.

Rosenlof, K. H., Tuck, A. F., Kelly, K. K. Russel, J. M., and McCormick, M. P.: Hemispheric asymmetries in water vapor and inferences about transport in the lower stratosphere, J. Geophys. Res., 102(D11), 13 213-13 234, doi:10.1029/97JD00873, 1997.

Schoeberl, M. R.: Extratropical stratosphere-troposphere mass exchange, J. Geophys. Res., 109, D13303, doi:10.1029/2004JD004525, 2004.

Sprenger, M. and Wernli, H.: A northern hemispheric climatology of cross-tropopause exchange for the ERA15 time period (1979-1993), J. Geophys. Res., 108(D12), 8521, doi:10.1029/2002JD002636, 2003.
Seo, K.-H. and Bowman, K. P.: A climatology of isentropic cross-tropopause exchange, J. Geophys. Res., 106(D22), 28 15928 172, doi:10.1029/2000JD000295, 2001.

Stohl, A., Bonsanoni, P., Cristofanelli, P., et al.: Stratospheretroposphere exchange: A review, and what we have learned from STACCATO, J. Geophys. Res., 108(D12), 8516, doi:10.1029/2002JD002490, 2003.

Tuck, A. F., Hovde, S. J., Kelly, K. K., et al.: Horizontal variability $12 \mathrm{~km}$ below the tropical tropopause, J. Geophys. Res., 109, D05310, doi:10.1029/2003JD003942, 2004.

Van Dorland, R. and Fortuin, J. P. F.: Simulation of the observed stratospheric temperature trends 1967-1987 over Antarctica due to ozone hole deepening, in: Non $\mathrm{CO}_{2}$ Greenhouse Gases, edited by: van Ham, J., Jansen, L. H. J. M., and Swart, R. J., p. 237-245, Kluwer Acad., Norwell, Mass., 1994.

Volz-Thomas, A., Berg, M., Heil, T., Houben, N., Lerner, A., Petrick, W., Raak, D., and Pätz, H. W.: Measurements of total odd nitrogen $\left(\mathrm{NO}_{\mathrm{y}}\right)$ aboard MOZAIC in-service aircraft: instrument design, operation and performance, Atmos. Chem. Phys., 5, 583595, 2005,

SRef-ID: 1680-7324/acp/2005-5-583.

Wang, P. K.: Moisture plumes above thunderstorm anvils and their contributions to cross-tropopause transport of water vapor in midlatitudes, J. Geophys. Res., 108(D6), 4194, doi:10.1029/2002JD002581, 2003.

Wernli, H. and Davies, H. C.: A Lagrangian-based analysis of extratropical cyclones. I: The method and some applications, Quart. J. Roy. Meteor. Soc., 123, 467-489, 1997.

Wernli, H. and Bourqui, M.: A Lagrangian "1-year climatology" of (deep) cross-tropopause exchange in the extratropical Northern Hemisphere, J. Geophys. Res., 107(D2), 4021, doi:10.1029/2001JD000812, 2002.

Wienhold, F. G., Fischer, H., Hoor, P., Wagner, V., Königstedt, R., Harris, G. W., Anders, J., Grisar, R., Knothe, M., Riedel, W. J., Lübken, F. J., and Schilling, T.: TRISTAR - a tracer in situ TDLAS for atmospheric research, App. Phys. B, 67, 411-417, 1998.

Wirth, V., Borth, H., Lopez, J. F., Panhans, W. G., Riemer, M., and Szabo, T.: Dynamics in the Extratropical Tropopause Region: a Case of Transition between Dynamically Active and Passive Tracer Advection?, Quart. J. Roy. Met. Soc., 131, 247-258, 2005.

WMO (World Meteorological Organization): Scientific Assessment of Ozone Depletion: 2002, Global Ozone Research and Monitoring Project, Report No. 47, 498 pp., Geneva, 2003.

Zöger, M., Afchine, A., Eicke, N., Gerhards, M.-T., Klein, E., McKenna, D. S., Mörschel, U., Schmidt, U., Tan, V., Tuitjer, F., Woyke, T., and Schiller, C.: Fast in situ stratospheric hygrometers: A new family of balloonborne and airborne Lyman- $\alpha$ photofragment fluorescence hygrometers, J. Geophys. Res., 104, 1807-1816, 1999 